\title{
Creditor Rights and Entrepreneurship: Evidence from Fraudulent Transfer Law*
}

by

\author{
Nuri Ersahin \\ University of Illinois
}

Rustom M. Irani

University of Illinois

\author{
Katherine Waldock \\ New York University
}

\begin{abstract}
CES 16-31
July, 2016

The research program of the Center for Economic Studies (CES) produces a wide range of economic analyses to improve the statistical programs of the U.S. Census Bureau. Many of these analyses take the form of CES research papers. The papers have not undergone the review accorded Census Bureau publications and no endorsement should be inferred. Any opinions and conclusions expressed herein are those of the author(s) and do not necessarily represent the views of the U.S. Census Bureau. All results have been reviewed to ensure that no confidential information is disclosed. Republication in whole or part must be cleared with the authors.

To obtain information about the series, see www.census.gov/ces or contact J. David Brown, Editor, Discussion Papers, U.S. Census Bureau, Center for Economic Studies 5K034A, 4600 Silver Hill Road, Washington, DC 20233, CES.Papers.List@census.gov. To subscribe to the series, please click here.
\end{abstract}




\begin{abstract}
We examine entrepreneurial activity following the adoption of fraudulent transfer laws in the U.S. These laws strengthen creditor rights by removing the burden of proof from creditors attempting to claw back funds that were transferred out of failing businesses. These laws are particularly important for entrepreneurs whose personal assets are often commingled with those of the venture. Using establishment-level data from the U.S. Census Bureau, we find significant declines in start-up entry, churning among new entrants, and closures of existing ventures after the passage of these laws. Our findings suggest that strengthening creditor rights can, in some circumstances, impede entrepreneurial activity and slow down the process of creative destruction.
\end{abstract}

Keyword: Creditor Rights; Bankruptcy; Entrepreneurship; Creative Destruction; Law and Finance Ersahin

JEL Classification: G21; G33; K22; L26; M13

\footnotetext{
*Ersahin (ersahin2@illinois.edu) and Irani (rirani@illinois.edu) are with the College of Business at the University of Illinois at Urbana-Champaign. Waldock (kwaldock@stern.nyu.edu) is with the Stern School of Business at New York University. We thank Viral Acharya, Kose John, Holger Mueller, Anthony Saunders, David Yermack, and Frank Limehouse at the Chicago Census Research Data. The research in this article was conducted while the authors were Special Sworn Status researchers of the U.S. Census Bureau at the Chicago Census Research Data Center. Any opinions and conclusions expressed herein are those of the authors and do not necessarily represent the views of the U.S. Census Bureau. All results have been reviewed to ensure that no confidential information is disclosed.
} 


\section{"[A]n understanding of debtor-creditor law, particularly fraudulent transfer law, is critical. A planner who purports to put together asset protection plans who has anything less than a thorough knowledge of the fraudulent transfer law is a fraud." \\ -Asset Protection: Concepts and Strategies for Protecting Your Wealth, Ad- kisson and Riser, 2004.}

The entrepreneur's decision to open or continue a venture is complicated. Consider an entrepreneur whose small business is struggling and who has unsecured debt outstanding. Beyond the assets pledged as collateral or protected by state personal property exemption laws, it may not be immediately clear what assets the owner may lay claim to. Does the owner have the right to keep retained earnings of the business from the year prior? Does the answer depend on whether those earnings were transferred to the personal bank account of a relative of the owner? May the owner claim some earnings of the current year as salary? These issues are largely governed by fraudulent transfer law, which are state regulations on the rights of a creditor to reverse transactions or transfers made by the business that affected the creditor's claims.

Fraudulent transfers are viewed legally in two ways: actual fraud or constructive fraud. Actual fraud refers to actions taken by the debtor with the intent to diminish the claims of its creditors. Constructive fraud refers to actions taken by the debtor that, as a result of the economic circumstances surrounding the transaction, ended up diminishing the claims of its creditors. In a state with fraudulent transfer laws based on actual fraud, the burden of proof is on the creditor to clearly demonstrate the fraudulent intent of the debtor. In a state with fraudulent transfer laws based on constructive fraud, however, all that is necessary is that debtor's business operations are sufficiently poor. A shift to a constructive-fraud based system therefore improves creditor rights, particularly those of unsecured creditors.

Allowing creditors to more easily reclaim assets that were transferred out of the business is a reduction in the costs of enforcing debt contracts. A state that adopts a constructive 
view of fraudulent transfers should then experience an expansion in credit supply. The effects on credit demand, however, are less clear. Transfers may be an important component of asset protection for certain businesses and therefore serve an insurance function by limiting the owner-manager's downside risk. Such a law change might then cause risk-averse entrepreneurs to reduce credit demand 1 The equilibrium level of credit therefore depends on the relative responses of those supplying credit to the marginal business owner.

We study the real impact of an increase in unsecured creditors' rights by employing a difference-in-differences (DiD) methodology that exploits the staggered adoption of constructive fraud statutes by states that formerly had lax fraudulent transfer policies.2 Drawing on establishment-level data from the U.S. Census Bureau, we find that states experience a significant decline entrepreneurial activity in the years following the adoption of constructive fraud laws. $3^{3}$ We observe substantial declines in both start-up entry and closure rates after the passage of constructive fraud laws. The decrease in entry rates occurs both among the smallest businesses that succeed and fail within three years of starting up, suggesting creditors are not able to screen out the riskier borrowers. We find similar negative effects when we compare start-up entry and exit with intensive margin adjustments made by incumbent, multi-unit firms that are unlikely to capture entrepreneurial activity. Taken together, these results indicate that expanding laws allowing unsecured creditors to reclaim a higher frac-

\footnotetext{
${ }_{1}^{1}$ Landier (2005) shows theoretically that debtor protection in bankruptcy is more suitable for entrepreneurship and innovation by fostering experimentation. In a related analysis, Manso (2011) demonstrates that the optimal compensation scheme to promotes innovation displays a substantial tolerance for failure, which is consistent with the use of debtor-friendly bankruptcy codes to motivate innovation.

${ }^{2}$ Most states have adopted fraudulent transfer regulations that have gradually become more favorable to creditors over time. In addition to statutory law, each state has its own case law standard by which it has interpreted the text of its statutes. Because of the difficulty in quantifying the true extent to which states assign rights to creditors with regards to avoidable transfers, we focus only on the three states plus the District of Columbia that went from having no statutory or case law allowing constructive fraud to adopting encompassing definitions of constructive fraud for the first time. This ensures that the adoption of the new statutory definitions of fraud really did constitute a major shift in the state's attitudes towards business transactions in or near insolvency. Further details are provided in Section 1.3

${ }^{3}$ Empirically, this paper follows Kerr and Nanda (2009) in the construction of state-level measures of firm entry, exit, and expansion using Census micro-data (see also Chemmanur et al., 2011, Delgado et al. 2010; Ellison et al. 2010).
} 
tion of assets upon business failure discourage start-up creation and extend the survival of old ventures, suggesting that entrepreneurs become constrained in their ability to redeploy assets into new and potentially more productive uses.

The discussion up to this point has focused on the impact of fraudulent transfer law on entrepreneurial activity. It is not immediately obvious, however, that redefining fraud should have a differential impact on small relative to large businesses. Indeed, it is common in large bankruptcies for unsecured creditors to pursue adversary proceedings, or suits that are separate from but related to the bankruptcy case, based on the avoidance of transfers. We posit that the impact of constructive fraud laws, to the extent that they hinder business growth, should be stronger for start-ups because, first, entrepreneurs are more likely to have personal assets co-mingled with those of the business, and second, large businesses are more likely to reorganize or have control over matters of jurisdiction in insolvency. In order to support these views, we examine heterogeneity of the average treatment effect. Sorting based on organizational form and size, we find that the effects are driven by singleunit firms and the smallest firms with between one and five employees. These effects hold even within state-year-industry cells, which alleviates the concern that coincident state-level unobservable factors such as the non-economic legal environment or social dynamics may have led to the decline in start-up creation. Furthermore, we find that effects are present only for firms in industries with low levels of start-up capital, where owners' financing using personal assets as collateral is more likely to be feasible.

Because state laws are often open to interpretation, it can be difficult to measure the strictness with which various statutes apply. An additional challenge is that during our event window, only the District of Columbia, Iowa, Kansas, and Vermont underwent drastic fraudulent transfer law changes. To ensure a broad effect, we show that the results hold for each of these states individually. We run additional tests including Indiana, which had some case law on constructive fraud prior to the passage of new statutory law, and find consistent 
results. The inclusion of states that had some pre-existing statutory law on constructive fraud and then passed comprehensive definitions of constructive fraud, however, weaken the results. We also check for robustness by excluding Alaska, which never passed constructive fraud laws, excluding states that were treated immediately prior to the sample horizon, and excluding Louisiana which went through a period of uncertainty regarding the statutory law on fraudulent transfers. In all of these tests, the results are still significant and magnitudes increase. As a further test of robustness, we show that the results were not driven by changes to the separate but related laws on insider preferences which, in some cases, happened concurrently to changes in the definition of fraud.

We attribute the decrease in entrepreneurship to a reduction in demand for credit by riskaverse individuals who wish to avoid states of the world that involve the loss of their own personal assets. As discussed in Severino et al. (2014), however, we cannot assess the welfare impact of this type of law change because it is difficult to test whether the assumed model is correct. Our view is that markets are incomplete and that affording more rights to creditors, while expanding the contract space, has adverse consequences for risk-sharing. Traditional corporate finance theory may attribute the decrease in entry to frictions related to nonverifiable cash flows or private benefits of running one's own business and therefore early liquidation, even when borrowers and lenders are both risk-neutral. Another confounding factor is that these law changes reduced the amount of outright fraud and that this was beneficial for state economies on net even if some non-fraudulent businesses also stayed out of the market. Because of our inability to test precise modeling choices and observe details about the change in composition of firms, we are limited in the extent to which we can determine the welfare of implications of this study.

Our paper contributes to the literature on the relationship between law, credit markets, and growth that began with the work of La Porta et al. (1998). This literature initially connected strong creditor protections with favorable credit market conditions in cross-country 
analyses, evolving to show that in some circumstances creditor rights might be too strong and have adverse consequences. ${ }^{4}$ Our approach relates to recent studies seeking to establish causality using within-country regulatory changes to identify exogenous variation in creditor rights. Notably, Visaria (2009) and von Lilienfeld-Toal et al. (2012) who analyze the effects of debt recovery tribunals in India that were brought about in order to reduce the cost of enforcing debt contracts. While Visaria (2009) finds that these tribunals improve repayment behavior and make loan terms more favorable, von Lilienfeld-Toal et al. (2012) find that they promote access to credit only for large borrowers while weakening access to credit for small borrowers. Vig (2013) observes a similar negative impact of a 2002 law in India that strengthened the rights of secured creditors. He finds that the reform led to reductions in asset growth and a substitution from secured to unsecured debt, consistent with large firms with multiple financing options contracting around a liquidation bias among creditors. Our contribution is to examine the importance of creditor rights for entry and exit rates among the entrepreneurial firms in the U.S. economy. Our results suggest that strengthening creditor rights, in particular, by allowing for greater access to entrepreneurs' personal assets in case of default, can impede entrepreneurship and the process of creative destruction.

Our paper is also related to the literature on personal bankruptcy exemptions. Gropp et al. (1997) were the first to connect state personal bankruptcy exemptions to credit conditions, finding that states with high bankruptcy exemptions eased credit conditions for wealthy borrowers and tightened credit conditions for low-asset households. Fan and White

\footnotetext{
${ }^{4}$ La Porta et al. (1997) find that countries with stronger investor and creditor protections have larger and more robust capital markets (see also, e.g., Giannetti, 2003, Qian and Strahan, 2007). Levine and Zervos (1998) find an association between strong creditor rights and better banking systems. Djankov et al. (2007) devote a portion of their analysis to countries that underwent reforms that strengthened creditor rights and find that they experienced higher rates of credit growth. Haselmann et al. (2010) demonstrate, more specifically, that countries that improved collateral laws were met with stronger credit markets and increases in economic activity (see also, Calomiris et al. 2016, Campello and Larrain, 2016). In contrast, Acharya and Subramanian (2009) find that changes to bankruptcy codes in favor of creditors result in lower investment in R\&D and levels of innovation (see also, Seifert and Gonenc, 2012). Similarly, Acharya et al. (2011) find that countries with strong creditor rights are associated with lower levels of risk-taking which, in turn, is detrimental to operating performance.
} 
(2003) find that states with high bankruptcy exemptions are associated with a higher probability that households own a business, attributing this effect to the insurance function of bankruptcy exemptions. Observing changes to exemption levels across states, Cerqueiro and Penas (2014) find that increases in personal wealth protections reduce the amount of credit that banks are willing to provide and that owner-managers of unlimited liability companies offset the reduction in external financing with personal wealth. Most similar in spirit to our study is Cerqueiro et al. (2015), who find that higher exemption limits reduce the number of patents generated by small firms in the U.S., suggesting that reductions in credit supply outweigh potential benefits of risk-sharing when it comes to risk-taking and exploration by innovators. We complement this work by, first, examining more broadly the effects of creditor rights on the various aspects of the entrepreneurial process and, second, by considering a novel aspect of creditor protection: the definition of fraudulent transfers.

The rest of this paper proceeds as follows. Section 1 reviews the institutional details surrounding the organizational structure of small businesses, small business failure, and the law of fraudulent transfers. Section 2 describes the data and empirical methodology. Section 3 discusses results. Section 4 concludes.

\section{Institutional Background}

\subsection{Organizational Structure and Personal Wealth Protection}

There are two important features that govern the interactions between a business owner and outside agents: the establishment of the business as a separate legal entity and the protection of the owner from unlimited liability. The line is generally drawn between sole proprietorships, which are not separate legal entities from the individual owner and do not protect the owner from unlimited liability, and limited liability companies (LLCs) or corporations, which stand on their own as legal entities and offer the owner limited liability 
protection.5 The liability status of partnerships depends on whether the partnership is a limited liability partnership (LLP) or a limited partnership (LP), the latter of which may involve general partners who are not protected by limited liability. According to the U.S. Small Business Administration, 72.1 percent of businesses are sole proprietorships while 18.5 percent are corporations (including S-types). 79.9 percent of businesses do not officially retain any employees other than the owner-manager, and 52 percent are home-based.

In addition to separate legal status and limited liability protection, simplicity is a key factor in corporate organization. In order to technically register as a sole proprietorship, owners in most states only need to obtain local licenses at the time of business formation ${ }^{6}$ These licenses are usually easy to obtain, inexpensive, and do not require annual updates. In addition, assets of the business owner are commingled with personal assets, and so it is not necessary to keep separate records. Conversely, LLCs and corporations are more costly and complicated to establish and keep track of. Business owners must pay not only organizational formation fees, but also filing fees and annual state fees. Even though income from LLCs and S-Corporations may pass through to the business owners for taxation purposes, recordkeeping is more complicated because these business forms have their own legal identities.

Regardless of organizational structure, there is only a fine line for most small businesses between personal assets and business assets. Even for businesses with limited liability protection, owners often utilize their own wealth as start-up capital by transferring titles of assets to the business. They also facilitate external borrowing by providing personal guarantees. Owners continually have to decide whether to reinvest profits into the business or withdraw cash in the form of salary or dividend payments. Because of this, asset protection

\footnotetext{
${ }^{5}$ LLCs may have an unlimited number of shareholders and can make disproportionate distributions to these investors, while S-Corporations are limited to 100 shareholders and distributions must be pro-rata. Otherwise, these two structures are very similar.

${ }^{6}$ Technically, any freelance income qualifies the earner as a sole proprietor. In general, it is not necessary to take any formal action to register as a sole proprietorship. Various types of business, however, required licenses and permits.
} 
has become a key component of small business planning.

Exemption planning and strategic transfers are the two main tenets of asset protection planning. The relative importance of these strategies depends on the business's organizational form. For proprietorships, the first line of defense is to make full use of state asset exemption laws. For businesses in states with paltry exemptions, or medium-sized businesses that involve assets that are significantly greater than the exemption threshold, strategic transfers play a more important role. Personal assets that have been transferred to a limited liability structure very rarely qualify for exemptions, and so transfers play a more important role in protecting assets of LLC or corporation owners.

Each state has its own set of rules governing exemptions that protect certain core personal assets from seizure by creditors. The homestead exemption is the most well known of these, followed by personal property exemptions. $7^{7}$ Other exemptions include pension and retirement benefits, insurance, tools of trade, earned but unpaid wages, and public compensation benefits such as Social Security. Some states even offer wildcards for any other type of personal property not covered, usually up to a small amount.

Other than direct exemptions, the primary tool that small business owners may use to protect personal property from creditors is through strategic funding, or transfers of assets into and out of the business. For businesses that are not protected by limited liability, this may involve the transfer of assets into trusts or to other individuals. Domestic asset protection trusts (DAPTs) are a form of wealth protection that shield assets from creditors but also allow the transferor to be the beneficiary of the trust. They are legal in 14 jurisdictions, but transfers of business assets into DAPTs have not received favorable treatment in insolvency proceedings. Offshore trusts used to be a popular form of asset protection, but have fallen

\footnotetext{
${ }^{7}$ Personal property exemptions are often further itemized, and limits are applied to each category, ranging from motor vehicles to burial plots.

8 Agarwal et al. (2005) finds that states with higher homestead exemptions are associated with higher bankruptcy rates, while Fan and White (2003) identify a positive but insignificant relationship between high exemption states and the likelihood that financially troubled businesses are shut down.
} 
out of favor more recently following several notorious cases 9 Alternatively, an individual providing a personal guarantee for a business debt may still legally transfer his home to his spouse and shield it from creditors provided that the spouse is not liable to those creditors and the transfer does not qualify as fraudulent, as discussed in Section 1.3 .

For LLC or corporation owners, protecting assets involves legally transferring them from the business to the individual. Cash may be withdrawn in the form of salary, dividend, and personal loan payments. Owner-managers are given the flexibility to determine their salaries, although how much they are able to pay is often governed by external factors. ${ }^{10}$ The IRS limits distributions in the form of salary, however, and usually bases its assessment of reasonable compensation to owner-managers on gross receipts, comparable businesses, and payments to non-shareholder employees. Salary payments in excess of the acceptable limit are treated as dividends. Real property may also be transferred from a business entity to an individual through a quitclaim deed. Finally, owners may strategically withdraw cash from LLCs or corporations by giving preference to personal loans made to the business or external loans that have been backed by a personal guarantee.

\subsection{Small Business Failure}

Although business failure is often synonymous with bankruptcy, bankruptcy is a distinct legal process that is governed in the U.S. by federal code. This code is divided into several chapters that relate to different types of bankrupt entities ${ }^{11}$ While Chapter 7 relates to both

\footnotetext{
${ }^{9}$ After filing for bankruptcy in 1997, Stephen J. Lawrence, founder of a derivatives trading firm, was found in contempt of court for establishing offshore asset protection trusts and served several years in jail. In 1999, Michael and Denyse Anderson were also found in contempt of court after refusing to repatriate funds kept in an offshore trust, and each spent six months in jail.

${ }^{10}$ Corporations, for example, must pay an additional employment tax on salaries distributed to owners, therefore incentivizing distribution through dividends. This tax levied on earnings of an LLC regardless of salary payments made to owners, while the income of sole proprietorships or partnerships are taxed as personal income regardless.

${ }^{11}$ Chapter 7 concerns asset liquidation, Chapter 9 the reorganization of municipalities, Chapter 11 complex reorganizations (generally of businesses), Chapter 12 reorganizations of family farms or fishermen, Chapter 13 reorganization for individuals, and Chapter 15 cross-border insolvency.
} 
small businesses as well as individuals wishing to liquidate substantially all of their assets, sole proprietors are often given the option to undergo either Chapter 11 or Chapter 13 proceedings if they hope to reorganize. Partnerships, LLCs, and corporations are not given the option of filing for Chapter 13. Because Chapter 11 is costlier, most sole proprietors that file for bankruptcy choose to file for Chapter 13, although eligibility is dictated by size restrictions on debt 12

Bankruptcy is not the only option for entrepreneurs, however. Because of filing fees, legal fees, long bankruptcy durations, loss of control over business operations, the automatic stay, and other indirect costs associated with bankruptcy, both debtors and creditors of small businesses often prefer avoid bankruptcy if possible ${ }^{13}$ Morrison $(2008,2009)$ provides a comprehensive overview of the small business decision whether to file for bankruptcy or cease operations based on other means when faced with insolvency. Using data from 2004 until 2006, these studies show that federal bankruptcy filings were only between 3 and 4 percent of business closures that took place among indebted businesses. When limited to businesses that closed while financially distressed based on the Dun \& Bradstreet financial distress score, the ratio of failing firms filing for bankruptcy jumps to between 10 and 13 percent for non-corporations and between 21 and 22 percent for corporations. Even based on stringent definitions, though, the majority of insolvent businesses liquidate or reorganize without filing for federal bankruptcy.

What are the alternatives to bankruptcy? The procedures in place typically derive from the laws of contracts, trusts, and secured lending, which are enforced in state courts based on each states' judicial organizational structure. The friendliest option is a private workout that avoids courts altogether. These agreements rely on the debtor's ability to arrange for a

\footnotetext{
${ }^{12}$ Currently, individuals with more than $\$ 383,175$ in unsecured claims and $\$ 1,149,525$ in secured claims may not file for Chapter 13 bankruptcy; see www.nolo.com/legal-encyclopedia/ chapter-13-chapter-11-bankruptcy-small-business-owners.html.

${ }^{15}$ Creditors may force debtors into involuntary bankruptcy, but this is not common in practice. Rather, it can be used as a bargaining chip for debtors in a private workout.
} 
plan of asset distribution in a way that satisfies all parties involved. Another option, at least for secured creditors, is to step in and foreclose on any assets in which they have a security interest. They may do so based on state laws set forth in the Uniform Commercial Code. If these actions are taken by secured creditors without impediments by debtors or unsecured creditors, then the process is known as a friendly foreclosure. Alternatively, if a business owner wishes to continue operations, similar to a restructuring under Chapter 11 of the Bankruptcy Code, then he has the option of undergoing a procedure called an "assignment for benefit of creditors" or ABC. In this case, a trustee receives the assets of the business and holds an auction ${ }^{14}$ Proceeds go towards the secured debt holders, unsecured debt holders receive nothing if the secured claimants are not made whole, and the old business ceases to exist as a legal entity. Often, though, the former business owner is able to repurchase most of the assets of the business and establish a new entity.

In any of these situations, aggrieved parties may attempt to delay proceedings or receive higher distributions by bringing suit against another party in state court. One course of action, also used frequently in bankruptcy proceedings, is referred to as an avoidance, and takes place when a previous transaction carried out by the business is undone. Transactions found to be fraudulent - the subject of this paper-are one example of commonly-sought avoidances. Preferential transfers, or transfers to a junior class of claim holders or to an equivalent class of claim holders in a way that is not pro rata, are also an important feature of fraudulent transfer law.

\subsection{The History of Fraudulent Transfer Law}

When a business becomes insolvent, all of the transactions made in its recent history become a matter of scrutiny. This is because owners may have undergone such transactions

\footnotetext{
${ }^{14}$ The details of these auctions vary by state. Trustees are not often required to go to great lengths to publicize these auctions, and the business owner may be able to reclaim the business physical assets as the sole bidder in the auction.
} 
in order to place assets beyond the reach of creditors, either for their own personal gain or so that the business may be able to survive longer. Given these incentives and the ability of most business owners to exert significant control over business assets, fraudulent transfer laws have been established in order to prevent debtors from absconding with the business's assets in the event of financial distress.

While fraudulent transfer law applies to all debtors, there are several reasons why it is particularly relevant to entrepreneurs. Information asymmetries are extreme because small businesses are subject to few, if any, financial reporting requirements and because monitoring costs are high for external lenders. The owner has significant control over business decisions, and does not have to report to a board or to outside shareholders. As discussed, the assets of small businesses are often commingled with the owner's personal assets, thus exacerbating incentives to hide assets from creditors when the business is in distress.

From the 18th to 20th centuries, most U.S. states adopted fraudulent transfer law from England, which is in turn based on the Statute of 13 Elizabeth (1571) and the decision of Twyne's Case (1601). The Statute of 13 Elizabeth declares void all transfers made with the "purpose and intent to delay, hinder or defraud creditors," while Twyne's Case laid out a set of "badges" that help prove criminal intent. As financial relationships became more complex, however, these statutes became quickly outdated. The archaic text setting out the rules of fraudulent transfer failed to lay out what types of creditors were protected, what types of transfers were relevant, what types of transferees were held liable (if any), whether insolvency was a necessary condition, and how exactly to prove fraud ${ }^{15}$

In 1918, the National Conference of Commissioners on Uniform State Law (NCCUSL)

\footnotetext{
${ }^{15}$ The entire text of most states' fraudulent transfer laws prior to the passage of a uniform act read roughly as follows: "Every gift, grant, conveyance, assignment or transfer of, or charge upon any estate, real or personal, or right or thing in action, or any rent or profit thereof, made with the intent to disturb, delay, hinder or defraud creditors or other persons, and every bond or other evidence of debt given, suit commenced, or judgement entered, with like intent, shall be void as against such creditors, purchasers, and other persons." I.L. R.S. 1874, p. 540, §4.
} 
decided to draft a law that would clarify and standardize fraudulent transfer laws in the U.S.. They came up with the Uniform Fraudulent Conveyance Act (UFCA), which was eventually adopted by 25 states in the following half-century. The key change brought about by the UFCA was that it removed the burden of proof of fraudulent intent, and instead introduced the concept of constructive fraud. Under the UFCA, it would no longer be necessary to prove intent as a mindset in order to undo a transfer by the debtor. Transactions made by near insolvent debtors, or debtors with sufficiently few assets, could now be legally overturned.

A version of the UFCA was incorporated into the Bankruptcy Act of 1938 and the Bankruptcy Reform Act of 1978 (1978 Act). In its current form, §547-548 of Chapter 11 dictate procedure on fraudulent transfers. Although Bankruptcy Code is federal, state fraudulent transfer laws may be invoked during a bankruptcy proceeding in place of $\S 548$ if one can prove a creditor would have benefited from the use of state law. Because the statute of limitations is usually longer in state law, many creditors find these laws favorable.

After the passage of the 1978 Act, the NCCUSL was reminded that half of the states still retained fraudulent transfer laws dating back to the 16th century. In addition, given the rise in complexity of debtor-creditor relations throughout the 20th century, many states had a multitude of contradictory case rulings. Because of this, judges were left to their own discretion to interpret the statutes as they saw fit. The NCCUSL commented that "[t]here are few legal subjects where there is greater lack of exact definitions and clear understanding" than fraudulent transfer law. ${ }^{16}$ In addition to pressure from those involved in the drafting of the 1978 Act, the NCCUSL was also influenced by a number of legal organizations including the Committee on Corporate Laws and the American Bar Association. A drafting committee for the Uniform Fraudulent Transfer Act (UFTA) was appointed in early 1983, and the law was approved in mid-1984.

The NCCUSL lacks the authority to enact legislation, however, and so following the

\footnotetext{
${ }^{16}$ Uniform Fraudulent Conveyance Act, 7A U.L.A. 428 (1985) (Prefatory note).
} 
approval of the UFTA, representatives of NCCUSL contacted state representatives and pressured them to adopt the new uniform act. This initiative was largely successful, and the UFTA was eventually put into law by 45 states and the District of Columbia. This gradual adoption took place over the 21 years spanning the period from 1985 until 2006. Table 1 presents the timing of passage of the UFTA 17

The UFTA was not a major overhaul of the UFCA, and so states that had already enacted the earlier version ended up with a relatively similar law following the change. The only major difference was the addition of a new section, $\S 5(\mathrm{~b})$, which invalidated preferential debt payments to insiders. Prior to this addition, states were relatively mixed in their approaches to insider preferences. Some treated it as a separate category of fraud and had explicit statutes on the voidability of this type of transaction, but most did not have any statutory law regarding this area and left it up to interpretations of fraudulent transfer. Several states, upon adopting the UFTA, opted out of this section. Of the states that had not already enacted the UFCA, some had adopted measures similar to the constructive fraud provisions in the uniform laws on their own. Those that retained statutes similar to 13 Elizabeth experienced the greatest change when they switched to the UFTA 18

Because of the incremental nature of changes that were made to the definition of constructive fraud and variations in case law across judges, it is difficult to measure the degree to which statutory law on fraudulent transfers has been deemed favorable towards creditors. In order to overcome this problem, we consider only states that had no statutory or case law on constructive fraud prior to the passage of the UFTA. To identify these states, we read the text of each state's annotated statutes. Portions of each state's statutes are

\footnotetext{
${ }^{17}$ Maryland and New York passed the UFCA in the early 20th century, but never the UFTA. Alaska, Kentucky, South Carolina, and Virginia have yet to adopt a uniform law on fraudulent transfers. Louisiana passed the UFTA in 2003, but almost immediately set in motion the steps to repeal it in 2004.

${ }^{18}$ In July 2014, the UFTA was renamed the Uniform Voidable Transactions Act (UVTA). Although the substance of the law was effectively unchanged, the new name now reflects the fact that the law gives creditors the power to undo a much broader set of transactions than those that fall within the scope of fraud.
} 
grouped by topic and updated every several years based on the frequency of changes. We compared each statute regarding transfers in the version immediately before the passage of the UFTA to the version immediately after the passage of the UFTA. We also read the case law for each statute related to fraudulent transfer. Ultimately, we focus on three states and the District of Columbia because they underwent drastic transitions from intent-based to constructive-based fraudulent transfer regimes.

\section{Data and Empirical Methodology}

We adapt the DiD framework of Kerr and Nanda (2009), who study the effect of statelevel bank branching deregulations on entrepreneurial activity. We believe their approach is well-suited to our own setting and thus we choose to follow their methods and terminology as closely as possible. Here, we describe our data sources, how key variables are constructed, and our empirical framework.

\subsection{Data Sources}

For legal data on each state, we use a variety of sources. First, we use state historical statutes, available through Hein's Superseded State Statutes and State Session Laws microfiche collections ${ }^{19}$ Superseded State Statutes provides a snapshot of each state's laws through time, while State Session Laws contains all laws passed by each state's general assembly in each year. Because of the incremental nature of changes that were made to the definition of constructive fraud, we construct a timeline of fraudulent transfer law for each state. To construct this timeline, we begin with the session law that introduced the UFTA, obtained from ThomsonWest's Uniform Laws Annotated. We then make use of the

\footnotetext{
${ }^{19}$ These collections were accessed through the New York University Law School Library. In some cases, state statutes were supplemented by West's State Statutes Annotated and Harrison Company's State Statutes Annotated.
} 
references to the prior fraudulent conveyance laws that were either amended or repealed by UFTA, which is provided in the text of UFTA for most adopting states. We retrieve the most recent version of the fraudulent conveyance law either amended or repealed by UFTA from the Superseded State Statutes. That way we can get a detailed picture of the evolution of each state's laws through time given that in nearly all states, these Statutes are annotated with the relevant history of amendments as well as case law pertaining to the statute. ${ }^{20}$

The establishment-level data set used in our analysis is the Longitudinal Business Database (LBD), which is provided by the U.S. Census Bureau. Our sample spans the period from 1992 until 2007. The LBD is an annual registry of all private business establishments in U.S., which are identified as locations with at least one paid employee. The data contain information on number of employees, payroll, industry codes, and physical location for each establishment at the annual frequency. The LBD also provides information on corporate ownership, which helps us identify to which firm an establishment belongs to in a given year. These corporate affiliation data are crucial for the correct measurement of entrepreneurial activity, as entering establishments might represent an expansion of a potentially large preexisting ("multi-unit") firm as opposed to start-up activity (i.e., entry by a standalone or "single-unit" firm). Such distinctions cannot be made with publicly-available, aggregated versions of the Census data (for example, the County Business Patterns data).

A key variable for our analysis is the amount of capital required to start a firm. Since the adoption of fraudulent transfer law is particularly important for entrepreneurs whose personal assets are commingled with business' assets, its effect on business creation might vary across industries depending on the amount of start-up capital required. The Characteristics of Business Owners (CBO) Survey, which is a part of 1992 Economic Census, provides economic

\footnotetext{
${ }^{20}$ For Oregon, we retrieve case law on fraudulent conveyances prior to the UFTA from Westlaw Next. For states that either did not adopt UFTA (South Carolina, Alaska, Kentucky, and Virginia) or where references to repealed statutes were not available in the text of UFTA (Arkansas, Hawaii, Kansas, Missouri), we constructed a legal history by canvassing all laws concerning debtor-creditor relations, statutes of fraud, and bulk transfer laws. All these states except for Hawaii had fraudulent transfer laws resembling 13 Elizabeth.
} 
and demographic information on business owners in the U.S. Following Hurst and Lusardi (2004), we use the survey response to the question "Total Capital Needed by Owner to Start/Acquire the Business by Industry Division" to determine the amount of start-up capital required at the industry level.

\subsection{Variable Construction and Summary Statistics}

We focus on four dependent variables to measure the effects of the UFTA on various aspects of entrepreneurial activity: business starts, the successes and failure rates of new businesses, and the closure rates of incumbent establishments. These variables are measured at the state-year and state-industry-year levels. We further disaggregate these measures by establishment size (i.e., number of employees) and firm type, where the latter indicates whether entry or exit occurs at a stand-alone firm or among the facilities of a multi-unit firm.

The first dependent variable is the natural logarithm of number of new establishments. We define the year of entry to be the first year with positive employment. We define entrepreneurship as the entry of new, stand-alone firms (e.g., Kerr and Nanda, 2009). The second and third dependent variables are related to the subsequent survival of these entrants. The LBD provides establishment identifiers that allow us to track them over time and identify exits. We focus on a three-year window after entry and define "churning entrants" as the $(\log )$ number of establishment entries that close within this period. We analogously define "long-term entrants" as the (log) sum of those entering establishments that survive three years. Finally, we also consider the $(\log )$ number of establishment closures, where the establishment-level year of closure is defined to be the last year with positive employment. This measure captures the closure rate among both entrant and incumbent establishments.

The main independent variable is an indicator variable taking the value of one if the state has any history of defining fraud constructively. This includes states that have passed 
the UFCA or UFTA, states with "good consideration" or "voluntary conveyance" statutes, or states in which any case law allowing creditors to avoid transfers based solely on the economic circumstances of the debtor exists. The indicator variable takes the value of zero if the state has no case law allowing creditors to reverse transfers based solely on the economic circumstances of the debtor and the statutory law either contains no mention of fraudulent transfers or its fraudulent transfer statutes were based on 13 Elizabeth. This is our preferred definition of the independent variable as it ensures that we identify off of states adopting constructive fraud law for the first time.

Table I presents the adoption year of fraudulent transfer laws on a state-by-state basis. We see that Alaska, Kentucky, Maryland, New York, Pennsylvania, South Carolina, and Virginia do not adopt the UFTA. We also see the effective year of insider preference laws and, in the final column, whether there is a pre-existing law on fraudulent transfers prior to the passage of the UFTA for each state. To illustrate how our independent variable works, consider Alabama (AL) and Iowa (IA). We see that Alabama and Iowa adopted the UFTA in 1990 and 1995, respectively. However, Alabama had either case or statutory law defining fraud constructively, whereas Iowa did not. Thus, the independent variable always takes the value of one for Alabama, whereas it takes the value of zero before 1995 and one after 1995 for Iowa. Our definition of treatment variable coupled with our event window from 1992 until 2010 confines our analysis to three states, Kansas, Iowa, Vermont, and the District of Columbia that switch from being untreated to treated 21

Table II presents summary statistics for entering establishments between 1992 and 2007. Entering establishments are classified into two groups: churning entrants, which close within three years of entry, and long-term entrants, which survive at least three years. Entry is further broken down according to firm status. Single-unit entry indicates the entering establishment is a new stand-alone firm, which we interpret as entrepreneurship. On the other

\footnotetext{
${ }^{21}$ We have restricted access to the confidential U.S. Census Bureau LBD for this event window only.
} 
hand, multi-unit entry corresponds to expansions of already existing firms along the extensive margin. The statistics reported in Table II provide information about the size, sector,

and geography of entering establishments. Several notable facts emerge. First, single-unit firms constitute 83 percent of all the entrants. The majority of entrants survive for longer than three years with 66 percent being long-term versus 34 percent churning entrants. Second, the size distribution indicates that most (70 percent) of these new businesses start with between one and five employees. On average, churning entrants start with fewer employees than long-term entrants. The industry sector distribution statistics shows the spread of our sample across Manufacturing, Services, Wholesale Trade, Retail Trade, Mining, Construction, and Transportation. We see that the majority of entrepreneurs start their businesses in the Services and Retail Trade industries with 43 percent and 22 percent, respectively.

\subsection{Identification and Empirical Model}

To examine how changes in creditor rights may impact entrepreneurial activity, we begin our analysis at the state-year level with the following specification:

$$
\mathrm{y}_{s t}=\alpha_{s}+\alpha_{t}+\beta \cdot \mathrm{UFTA}_{s t}+\epsilon_{s t},
$$

where $s$ indexes states and $t$ indexes years. The variable y stands for one of four measures of establishment entry and exit: the total number of entrants, the number of churning entrants, the number of long-term entrants, or the number of closures. We take the natural logarithm of each of these variables. $\mathrm{UFTA}_{s t}$ is an indicator variable that equals one if the state has any case or statutory law defining fraud constructively, and zero otherwise. $\alpha_{s}$ and $\alpha_{t}$ are state and year fixed effects, respectively. Since the analysis is based on a state-year panel dataset, we cluster standard errors by state.

The coefficient of interest, $\beta$, measures the average response in percentage points of the 
measure of entrepreneurial activity to the adoption of constructive fraud law for the first time. If entrepreneurs face financial constraints and the increase in creditor rights expands the supply of credit, then $\beta$ will be strictly positive for all measures of entry and exit. Greater access to credit may lead to increases in entry as well as churning and exit among new entrants, which are all important components of the entrepreneurial process. On the other hand, if risk-averse entrepreneurs with personal assets tied up in their ventures reduce demand for credit, then we may observe a slow down in entrepreneurial activity, which corresponds to $\beta$ strictly negative. The null hypothesis is that constructive fraud law is irrelevant for entrepreneurial activity (because entrepreneurs' personal assets are not tied up in their ventures, financial constraints are not binding, or creditor rights are unaffected by constructive fraud law), which corresponds to expecting that $\beta$ will be zero.

Identification of $\beta$ in Equation (1) exploits changes in entrepreneurial activity within-state around the adoption constructive fraud law for the first time. There are several identification concerns with this approach that we will now discuss.

The first potential issue concerns our definition of treated and control states. Our focus is on those states that underwent the most dramatic change in fraudulent transfer law. In particular, we define constructive fraud (treated) states as those with any precedent in defining fraud in the constructive sense (either according to statutory or case law), which results in nearly all states meeting this condition by the end of our event window. In fact, Alaska is the only state that never adopted the constructive fraud definition of voidable transfers. In order words, the control group consists of states that are already treated, eventually treated during the sample horizon, as well as Alaska, which is never treated. This classification of states may present a problem if, for example, early adopters of constructive fraud statutes exhibit different growth trajectories. In this case we may have a violation of the parallel trends assumption of of DiD model.

We examine this concern in the following ways. Most importantly, we estimate a dynamic 
version of Equation (1) with indicator variables showing the timing relative to the passage of UFTA in each state. Within this framework, we can examine if there are any pre-existing differential trends in the start-up entry and exit rates between the treated and control groups. We also directly examine if treatment sets states on permanently different growth trajectories, which could compromise the internal validity of our approach. To complement this analysis of dynamics, we consider several alternative control group classifications that either remove the never treated (Alaska) or the states that were treated close to the beginning of our event window. We defer the details of these tests to Section 3.5.

The second major concern is that there might be unobservable economic factors correlated with the law change affecting investment opportunities for all firms, including start-ups. To mitigate this concern, we first show that with the exception of population, which is negatively associated with the passage of the law, the timing of these laws was uncorrelated with broader macroeconomic trends (see Appendix A). In addition, we exploit the granularity of the LBD and compare activity between single- and multi-unit firms in the same state of location, industry and year. Since multi-unit entrants correspond to expansions of already existing firms they are unlikely to represent start-up activity (Kerr and Nanda, 2009). Thus, we use establishment entry and exit rates of already existing, multi-unit firms as a control group to demonstrate that the strengthening of creditor rights only impacts entrepreneurs' incentives. To implement this test, we estimate a stricter version of Equation (1) that separately compares both single-unit and multiple-unit entrants as follows:

$$
\mathrm{y}_{s i t x}=\alpha_{s i x}+\alpha_{t x}+\alpha_{s i t}+\beta \cdot \mathrm{UFTA}_{s t} \times \text { Single-Unit }_{x}+\epsilon_{s i t x}
$$

where $s, t, i$, and $x$ stand for state, year, industry, and type of firm, respectively. Type $\mathrm{f}_{x}$ is an indicator variable that equals one for single-unit firms, allowing us to differentiate between single-unit and multi-unit firms. Industries are grouped at the two-digit Standard Industrial 
Classification (SIC) level and we exclude the financial and public administration industries.

We fully saturate the model with fixed effects, $\alpha_{s i x}, \alpha_{t x}$, and $\alpha_{s i t}$ at the state-industry-type, time-type, and state-industry-type levels, respectively. The state-industry-year fixed effects are included to sweep out common factors affecting the investment opportunities of both start-ups and multi-unit firms. We now cluster standard errors at the state-type level to account for the disaggregation of our panel data. The coefficient $\beta$ now measures the mean percentage point response of entrepreneurs relative to multi-unit firms following the passage of UFTA.

The final concern is that other regulatory changes might occur in conjunction with the first adoption of constructive fraud law. We are particularly interested in changes in antiinsider preference laws, which invalidated preferential payments to insiders, as described in Section 1.3. It is unclear whether these laws have similar effects on credit supply and demand among start-ups, since they target owners' discretion over making payments to insiders as they approach insolvency. While anti-insider preference laws were often passed at the same time as the first adoption of a constructive definition of fraud, this is not always the case (see Table (1). This permits a separate analysis of entrepreneurial activity among states adopting anti-insider preference laws relative to a control group of states that do not. We implement this test by re-estimating Equation (11) with an independent variable that takes the value of one if an insider preference law was passed in that state and zero otherwise.

\section{Empirical Results}

We first estimate the average effect of the UFTA on establishment entry and exit rates at the state-year level in Section 3.1. Section 3.2 explores the dynamics of this average effect. Sections 3.3 and 3.4 presents the estimates by start-up capital amounts and by the initial employment level of entrants, respectively. Section 3.5 conducts several robustness checks. 


\subsection{Effect of the UFTA on Establishment Entry and Exit}

The strengthening of creditor rights - in our context through a constructive definition of fraud - has a theoretically ambiguous effect on entrepreneurial activity in equilibrium. It may increase entrepreneurship by expanding access to credit for financially constrained entrepreneurs or slow down entrepreneurship if risk-averse business owners fear personal assets will be clawed back by creditors in the event-of-default. These competing hypotheses are tested in Table III, where we estimate Equation (1) with the $(\log )$ number of total, churning and long-term entrants, and number of establishment closures as dependent variables.

Column [1] shows the effect of the UFTA on the total number of entering establishments at the state-year level. Establishment entry is defined to be the first year with positive number of employees for an establishment. We see that the coefficient on UFTA is -0.066, which is significant at 1 percent confidence level. Thus, our DiD estimate indicates that the passage of UFTA is associated with economically large effect on entrepreneurship: a 6.6 percent decrease in number of new entrants.

Columns [2] and [3] report the effect of the UFTA on the number of churning and longterm entrants, respectively. Churning entrants are entrants that close within 3 years of entry, whereas long-term entrants survive for at least 3 years. The DiD estimates are -0.073 and -0.064 for churning and long-term entrants, respectively, and both statistically significant at 1 percent confidence level. In Column [4], we look at the effect of UFTA on establishment

closures. We define the year of closure to be the last year with a positive number of employees. The estimated coefficient on UFTA is -0.065 and continues to be statistically significant at the 1 percent confidence level. Evidently, both the business creation and failure decrease following the passage of the UFTA. This indicates that the strengthening of creditor rights not only decreases new business formation but also increases the survival of old businesses. These effects are consistent with owners reducing risk-taking when their personal assets are at stake. 
The results so far suggest that the passage of constructive fraud laws is associated with a decrease in both establishment entry and exit rates. One potential concern with this finding is that some of these entering or exiting establishments may belong to large, incumbent firms that are not necessarily representative of entrepreneurial activity. To address this concern, we estimate Equation (1) separately for establishments belonging to both singleand multi-unit firms. The results of this estimation are shown in Table IV.

Columns [1] and [2] report the effect of adopting the UFTA on the number of entrants for single and multi-unit firms, respectively. We see that strengthening creditor rights decreases single-unit firm entry by 9.6 percent, which is about 50 percent larger than the baseline effect and statistically significant at the 1 percent level, whereas it has no statistically significant impact on expansion of already existing, multi-unit firms. The remaining columns of Table IV indicate similar results emerge when we focus on other aspects of the entrepreneurial process in the wake of the law change. In each case, only the entry and exit rates of singleunit firms are affected. These results confirm that the law change only has an impact on churning among start-ups, which are the types of firms likely to have owners' personal and business assets commingled.

\subsection{Dynamic Analysis of Entry and Exit}

Table $\mathrm{V}$ provides a nonparametric estimation of the treatment effect dynamics at the state-year level. Rather than having a single indicator variable switching on after each adoption of the UFTA, we modify Equation (1) to include four indicator variables: the first is for the two years before to the law change; the second for the year of the law change and the following year; the third is for the subsequent two years; and the final indicator is for the fourth and all years after the law change. The coefficients on each of these indicator variables measure entry and exit rates relative to the corresponding rates in the period at least three years prior to the law change, which is a suitable approach given the short length 
of time before the first law change 22 For this analysis, we focus on the entry and exit rates of single-unit firms, since they better capture entrepreneurship and we know from Table IV that this is where the treatment effect is located.

Turning to the estimates in columns [1] to [4], three notable facts emerge. First, we observe that the effects of the UFTA do not show up immediately, but instead take between two and three years to materialize. The estimated effects on two and three years after the passage of the UFTA and year four and thereafter are both statistically different from zero. The estimated entry rate for start-ups four or more years after the law change is about 9.2 percent lower than entry rates at least three years prior. We find similar effects for churning and long-term entry. Second, establishment closure rates decrease only four years out, which makes sense given churning entry begins to wane in the second year and beyond. Third, the coefficients on all entry and exit measures are indistinguishable from zero for the two years prior to the law change.

These patterns of entry and exit after the adoption of the UFTA are therefore consistent with previous results. Crucially, they confirm there are no pre-existing trends between treated and control states, which is consistent with the parallel trends assumption of our benchmark DiD model.

\subsection{Effect of the UFTA by Start-Up Capital Amount}

We have reasoned thus far that the strengthening of creditor rights matters more for start-ups in which owners' personal and business assets are commingled. For such firms under a constructive definition of fraud, creditors would be better positioned to recover their claims using the personal assets of the entrepreneur should the venture fail. In this section, we provide a direct test of this argument by performing sample splits according to

\footnotetext{
${ }^{22}$ Similar results (untabulated) obtain when we consider the dynamics of the treatment effect on a yearby-year basis from six years before to six years after the adoption of the UFTA.
} 
the amount of capital required to start a new business.

Sectors requiring large, upfront investments (e.g., heavy manufacturing) have start-up capital requirements that are likely too large to be met with the use personal assets. On the other hand, owners operating in industries that need a smaller amount of start-up capital financing using personal assets as collateral is more likely to be feasible. Based on this logic and the approach of Hurst and Lusardi (2004) and Adelino et al. (2015), we sort industries on the basis of start-up capital required using survey data from the CBO Survey of the 1992 Economic Census. ${ }^{23}$ We then reestimate Equation (1) separately for industries with high and low needs for start-up capital.

The results presented in TableVI follow the predicted pattern. As indicated in columns [1] and [2], following the UFTA the number of start-ups decreases in industries that require low start-up capital, whereas we see no effect in high start-up capital industries. The estimated coefficient is -0.072 and is significant at 1 percent confidence level. Columns [3] to [6] show that this effect is seen in both churning and long-term entrants. The estimated coefficients are -0.064 and -0.077 for churning and long-term entrants, respectively, and significant at at least the 5 percent level. Finally, in columns [7] and [8], we see that establishment closures decrease for only low start-up capital industries. Thus, we find that the effect of stronger creditor protection in decreasing entrepreneurial activity is pronounced among industries with lower start-up capital requirements.

\footnotetext{
${ }^{23}$ Based on the fraction of owners responding to the question "Total Capital Needed by Owner to Start/Acquire the Business by Industry Division" above or below $\$ 1,000,000$, we classify industries two-digit SIC industries as have high or low start-up capital need. Precisely, Manufacturing (20-39), Transportation, Communications, and Utilities (40-49), and Wholesale Trade (50-51) are classified as high start-up capital need. The remaining industries are classified as low start-up capital need: Agricultural Services, Forestry, Fishing, and Mining (01-14), Construction (15-17), Retail Trade (52-59), and Services (70-89).
} 


\subsection{Effect of the UFTA by Initial Employment}

We next characterize patterns of entry and exit across the establishment size distribution. This analysis provides a more accurate description of how the passage of the UFTA slowed down entrepreneurial activity. By estimating a stricter version of Equation (1), it also allows us to mitigate concerns regarding state-level unobservable factors that might jointly impact both the law change and investment opportunities.

Table VII reports our estimates of entry and exit rates with establishments classified according to their level of employment in the year of entry (or exit). We focus on the following size groupings: 1-5 employees, 6-20 employees, 21-100 employees, and greater than 100 employees ${ }^{24}$ We thus compare the establishment openings and closures rates of the two types of firms, single and multi-unit, at the same state of location, industry and year. We form our estimates based on Equation (2), which exploits the granularity of the LBD using a state-year-industry-type tuple as the unit of observation and fully saturates the model with firm type-year, state-industry-year, and state-industry-firm type fixed effects. Coefficients on the UFTA $\times$ Single-Unit indicator variable in these regressions capture the relative elasticity of start-up entry to facility expansions of multi-unit firms by employment size. Naturally, if the effect of the UFTA operates through the incentives of entrepreneurs then the slowdown in entry and exit rates should be among the smallest establishments of single-unit entrants.

Columns [1] to [4] of the table show the effect of the UFTA on total number of entrants for different size groups. In line with our expectation, we see that the effect of the UFTA on business formation is largest among single-unit firms with an initial number of employees between one and five. The estimated coefficient is -0.036 , which implies that the number of start-ups with between one and five employees decreases by 3.6 percent relative to the number of facility expansions of the same size by multi-unit firms in the same state, industry,

\footnotetext{
${ }^{24}$ For establishment closures, we construct the size groups based on final number of employees, i.e., the last positive number of employees reported in LBD before the closure.
} 
and year. The point estimate is significant at the 1 percent confidence level.

Similar patterns emerge when we look at the remaining columns. Columns [5] to [8] and [9] to [12] show analogous point estimates for churning and long-term entrants of -0.050 and -0.025, respectively. Columns [13] to [16] indicate that single-unit firms with between one and five employees reduce exit rates by 4.7 percent relative to unit closures by multi-unit firms. Similar patterns do not consistently emerge among single-unit entrants with greater than five employees.

Overall, we see that only entry and exit rates among the smallest single-unit start-up firms appear to be significantly affected by the adoption of the UFTA. These sized-based results are consistent with the hypothesis that the strengthening of creditor rights inhibits entrepreneurial activity. Importantly, they contrast with the alternative that start-up entry simply reflects changing investment opportunities at the state-level that may correlate with the adoption of the UFTA 25

\subsection{Further Robustness Checks}

The results of a series of robustness tests are presented in Table VIII. We first examine whether our results are an artifact of our modeling choices and, particularly, the definition of treated and control states. To this end, we repeat the estimation of Equation (1) for all firms and also single-unit (start-up) firms under a number of alternative assumptions to test the sensitivity of our results.

As described in Section 2.2, we choose to define our treatment variable to capture variation within states undergoing the most drastic change in creditor rights. Consequently, the District of Columbia, Iowa, Kansas, and Vermont are classified as treated states during

\footnotetext{
${ }^{25}$ We consider two further tests to control for state-level macroeconomic trends. First, we include stateyear control variables in the regression, consisting of the growth rate of population, number of employees, and total payroll. Second, we include only bordering states as a control group. We repeat the analysis presented in Tables III to VII and the results (untabulated) are similar.
} 
our sample period. In panel A, we first show that the basic patterns documented thus far hold for each of these states individually. Thus, we are not concerned that the peculiar circumstances of one of these four states is responsible for our findings.

In panel $\mathrm{B}$, we enlarge the treatment group. First, we include Indiana, which had only a limited history of case law on constructive fraud prior to the passage of new statutory law in 1994. We see that results do not change. Second, in addition to Indiana, we include Mississippi and North Carolina, which had vague pre-existing statutory law on constructive fraud but nevertheless adopted the UFTA in 2006 and 1997, respectively. Our results weaken considerably both in economic and statistical significance following the inclusion of these states to the treatment group. This last finding demonstrates that our benchmark effect occurs primarily among states undergoing the most meaningful change in creditor rights.

Thus far the control group has consisted of several subgroups: the never treated states, the eventually treated states, and the already treated states. Our identifying assumption is simply that the law changes occur at random, which is equivalent to a parallel trends assumption. While we have already demonstrated that there are no pre-existing differential trends among the control group, on average, there could be among one of the subgroups of control states and this could compromise the internal validity of our estimates. In panel C, we make several modifications to the control group to examine this possibility. First, we exclude Alaska, which never passed any statutory or case law regarding constructive fraud. We see that results are not affected. Second, we exclude Colorado, Maine, and Oregon, which were treated in 1991, 1986, and 1986, respectively. These three states were treated close to the beginning of our event window. We see that the exclusion of these three states from the already-treated group does not change the significance of our results ${ }^{26}$ Finally, our results are robust to the exclusion of Louisiana, which went through a period of uncertainty

\footnotetext{
${ }^{26}$ As a further robustness check, we code states already treated before the beginning of the event window as untreated and similar results (untabulated) obtain.
} 
regarding the statutory law on constructive fraud-Louisiana passed the UFTA in 2003, but almost immediately set in motion the steps to repeal it in 2004.

Our last set of tests examines the importance of anti-insider preference laws and checks if the slowdown in entrepreneurial activity we uncover is coincident with this regulatory change. Since they were not always passed concurrently with the first adoption of a constructive definition of fraud (see Table I), we can use our regression framework to compare establishment entry and exit rates among states adopting anti-insider preference laws relative to a control group of states that do not.

Table IX presents the results of this analysis using "Insider Preferences" - an indicator variable equal to one for any state adopting anti-insider preference laws - as the independent variable. We repeat each of the analyses presented in Table III through VII for the antiinsider states. Results in each panel confirm that anti-insider preference laws are not the driving force behind our main results. Indeed, for the various tests, we do not find a clear effect of anti-insider preferences on entrepreneurial activity. The point estimates are mostly insignificant and generally mixed in sign. This is in stark contrast to the estimates of the effect of the UFTA on establishment entry and exit rates, which show consistently negative pattern and are statistically significant across numerous specifications. ${ }^{27}$

\section{Conclusion}

The passage of the UFTA brought about two important changes to business law: it eliminated the burden of proof of fraudulent intent previously needed for creditors to undo a number of business transfers, and it reduced the ability of debtors to strategically pay off debts associated with more dire consequences in the event of default.

\footnotetext{
${ }^{27}$ We conduct two additional robustness checks on the importance of anti-insider preferences laws. First, we include indicator variables for both insider preferences and the UFTA in the same regression. Second, we repeat the analysis dropping states that pass constructive fraud laws from the control group. In both cases, similar results (untabulated) obtain.
} 
While businesses in states that underwent these changes likely experienced lower borrowing costs, our evidence demonstrates that it had negative effects on entrepreneurial activity. Using longitudinal establishment-level data from the U.S. Census Bureau, we find significant reductions in establishment entry and exit rates following the passage of the UFTA. These effects are present only among new, single-unit firms (i.e., entrepreneurs), as opposed to the expansions and contractions among larger, multi-unit firms, even within the same industry and the smallest employment size grouping, in a given state. Moreover, we only find an effect of the UFTA on start-ups requiring low initial levels of capital. These results point to the law change affecting the incentives of entrepreneurs beginning new ventures (or winding down existing ones) where personal assets have a higher weight both in operations and in the financing of the business.

Taken together, these results indicate that expanding laws allowing unsecured creditors to reclaim a higher fraction of assets upon business failure can discourage start-up creation and extend the survival of old ventures. This suggests that entrepreneurs may become constrained in their ability to redeploy assets into new and potentially more productive uses, thus inhibiting the process of creative destruction. 


\section{References}

Acharya, V., Amihud, Y., Litov, L., 2011. Creditor Rights and Corporate Risk-Taking. Journal of Financial Economics 102, 150-166.

Acharya, V. V., Subramanian, K. V., 2009. Bankruptcy Codes and Innovation. Review of Financial Studies 22, 4949-4988.

Adelino, M., Schoar, A., Severino, F., 2015. House Prices, Collateral, and Self-Employment. Journal of Financial Economics 117, 288 - 306.

Agarwal, S., Chomsisengphet, S., Liu, C., Mielnicki, L., 2005. Impact of State Exemption Laws on Small Business Bankruptcy Decision. Southern Economic Journal 71, 620-635.

Calomiris, C., Liberti, J., Larrain, M., Sturgess, J., 2016. How Collateral Laws Shape Lending and Sectoral Activity. Journal of Financial Economics, Forthcoming.

Campello, M., Larrain, M., 2016. Enlarging the contracting space: Collateral menus, access to credit, and economic activity. Review of Financial Studies 29, 349-383.

Cerqueiro, G., Hegde, D., Penas, M. F., Seamans, R., 2015. Debtor Rights, Credit Supply, and Innovation. Working Paper, New York University.

Cerqueiro, G., Penas, M. F., 2014. How does Personal Bankruptcy Law affect Start-Ups? Working Paper, Tilburg University.

Chemmanur, T. J., Krishnan, K., Nandy, D. K., 2011. How does Venture Capital Financing Improve Efficiency in Private Firms? A Look Beneath the Surface. Review of Financial Studies 24, 40374090.

Delgado, M., Porter, M. E., Stern, S., 2010. Clusters and Entrepreneurship. Journal of Economic Geography .

Djankov, S., McLiesh, C., Shleifer, A., 2007. Private Credit in 129 Countries. Journal of Financial Economics 12, 77-99.

Ellison, G., Glaeser, E. L., Kerr, W. R., 2010. What Causes Industry Agglomeration? Evidence from Coagglomeration Patterns. American Economic Review 100, 1195-1213.

Fan, W., White, M. J., 2003. Personal Bankruptcy and the Level of Entrepreneurial Activity. Journal of Law and Economics 46, 543-567.

Giannetti, M., 2003. Do Better Institutions Mitigate Agency Problems? Evidence from Corporate Finance Choices. Journal of Financial and Quantitative Analysis 38, 185-212.

Gropp, R., Scholz, J. K., White, M. J., 1997. Personal Bankruptcy and Credit Supply and Demand. Quarterly Journal of Economics 112, 217-251.

Haselmann, R., Pistor, K., Vig, V., 2010. How Law Affects Lending. Review of Financial Studies 23, 549-580. 
Hurst, E., Lusardi, A., 2004. Liquidity Constraints, Household Wealth, and Entrepreneurship. Journal of Political Economy 112, 319-347.

Kerr, W. R., Nanda, R., 2009. Democratizing Entry: Banking Deregulations, Financing Constraints, and Entrepreneurship. Journal of Financial Economics 94, 124-149.

La Porta, R., Lopez-De-Salines, F., Shleifer, A., Vishny, R. W., 1997. Legal Determinants of External Finance. Journal of Finance 52, 1131-1150.

La Porta, R., Lopez-de Silanes, F., Shleifer, A., Vishny, R. W., 1998. Law and Finance. Journal of Political Economy 106.

Landier, A., 2005. Entrepreneurship and the Stigma of Failure. Working Paper, Toulouse School of Economics.

Levine, R., Zervos, S., 1998. Stock Markets, Banks, and Economic Growth. American Economic Review 88, 537-58.

Manso, G., 2011. Motivating Innovation. Journal of Finance 66, 1823-1860.

Morrison, E., 2008. Bankruptcy's Rarity: An Essay on Small Business Bankruptcy in the United States. European Company and Financial Law Review 5, 172-188.

Morrison, E. R., 2009. Bargaining around Bankruptcy: Small Business Workouts and State Law. Journal of Legal Studies 38, 255-307.

Qian, J., Strahan, P. E., 2007. How Laws and Institutions Shape Financial Contracts: The Case of Bank Loans. Journal of Finance 62, 2803-2834.

Seifert, B., Gonenc, H., 2012. Creditor Rights and R\&D Expenditures. Corporate Governance: An International Review 20, 3-20.

Severino, F., Brown, M., Coates, B., 2014. Personal Bankruptcy Protection and Household Debt. Working Paper, Dartmouth College.

Vig, V., 2013. Access to Collateral and Corporate Debt Structure: Evidence from a Natural Experiment. Journal of Finance 68, 881-928.

Visaria, S., 2009. Legal Reform and Loan Repayment: The Microeconomic Impact of Debt Recovery Tribunals in India. American Economic Journal: Applied Economics 1, 59-81.

von Lilienfeld-Toal, U., Mookherjee, D., Visaria, S., 2012. The Distributive Impact of Reforms in Credit Enforcement: Evidence From Indian Debt Recovery Tribunals. Econometrica 80, 497-558. 


\section{Table I}

\section{Fraudulent Transfer Laws by State}

This table lists the effective year of fraudulent transfers and insider preference laws as well as indicates whether there is a pre-existing law on fraudulent transfers before UFTA for each state. Statutory refers to the text that is contained within the legal code of a state, whereas Case refers to what courts within a particular state have decided as precedent. The last column equals one if the state has some case or statutory law before the adoption of UFTA defining fraud constructively. It takes the value of N/A for states not adopting the UFTA.

\begin{tabular}{|c|c|c|c|}
\hline State & UFTA & $\begin{array}{c}\text { Insider } \\
\text { Preferences }\end{array}$ & $\begin{array}{l}\text { Statutory or Case } \\
\text { Law before UFTA }\end{array}$ \\
\hline $\mathrm{AL}$ & 1990 & 1990 & 1 \\
\hline AK & - & - & $\mathrm{N} / \mathrm{A}$ \\
\hline $\mathrm{AZ}$ & 1990 & - & 1 \\
\hline $\mathrm{AR}$ & 1987 & 1987 & 1 \\
\hline $\mathrm{CA}$ & 1986 & - & 1 \\
\hline $\mathrm{CO}$ & 1991 & 1991 & 0 \\
\hline $\mathrm{CT}$ & 1991 & 1991 & 1 \\
\hline $\mathrm{DE}$ & 1996 & 1996 & 1 \\
\hline DC & 1996 & 1996 & 0 \\
\hline FL & 1988 & 1988 & 1 \\
\hline GA & 2002 & 2002 & 1 \\
\hline HI & 1985 & 1985 & 0 \\
\hline ID & 1987 & 1987 & 1 \\
\hline IL & 1990 & 1990 & 1 \\
\hline IN & 1994 & - & 1 \\
\hline IA & 1995 & 1995 & 0 \\
\hline $\mathrm{KS}$ & 1999 & 1999 & 0 \\
\hline KY & - & 1970 & $\mathrm{~N} / \mathrm{A}$ \\
\hline LA & 1985 & 1985 & 0 \\
\hline $\mathrm{ME}$ & 1986 & 1986 & 0 \\
\hline MD & - & - & $\mathrm{N} / \mathrm{A}$ \\
\hline MA & 1996 & 1996 & 1 \\
\hline MI & 1998 & 1998 & 1 \\
\hline $\mathrm{MN}$ & 1987 & 1987 & 1 \\
\hline MS & 2006 & - & 1 \\
\hline $\mathrm{MO}$ & 1992 & 1992 & 1 \\
\hline $\mathrm{MT}$ & 1991 & 1991 & 1 \\
\hline NE & 1989 & 1989 & 1 \\
\hline NV & 1987 & 1987 & 1 \\
\hline $\mathrm{NH}$ & 1988 & 1988 & 1 \\
\hline NJ & 1989 & 1989 & 1 \\
\hline NM & 1989 & 1959 & 1 \\
\hline NY & - & - & $\mathrm{N} / \mathrm{A}$ \\
\hline $\mathrm{NC}$ & 1997 & 1997 & 1 \\
\hline ND & 1985 & 1943 & 1 \\
\hline $\mathrm{OH}$ & 1990 & 1961 & 1 \\
\hline OK & 1986 & 1986 & 0 \\
\hline OR & 1986 & 1986 & 0 \\
\hline PA & - & - & $\mathrm{N} / \mathrm{A}$ \\
\hline RI & 1986 & 1986 & 1 \\
\hline $\mathrm{SC}$ & - & - & $\mathrm{N} / \mathrm{A}$ \\
\hline SD & 1987 & 1919 & 1 \\
\hline TN & 2003 & 2003 & 1 \\
\hline $\mathrm{TX}$ & 1987 & 1987 & 1 \\
\hline $\mathrm{UT}$ & 1988 & 1988 & 1 \\
\hline VT & 1996 & 1996 & 0 \\
\hline VA & - & - & $\mathrm{N} / \mathrm{A}$ \\
\hline WA & 1988 & 1988 & 1 \\
\hline WV & 1986 & 1986 & 1 \\
\hline WI & 1988 & 1988 & 1 \\
\hline WY & 2006 & - & 1 \\
\hline
\end{tabular}




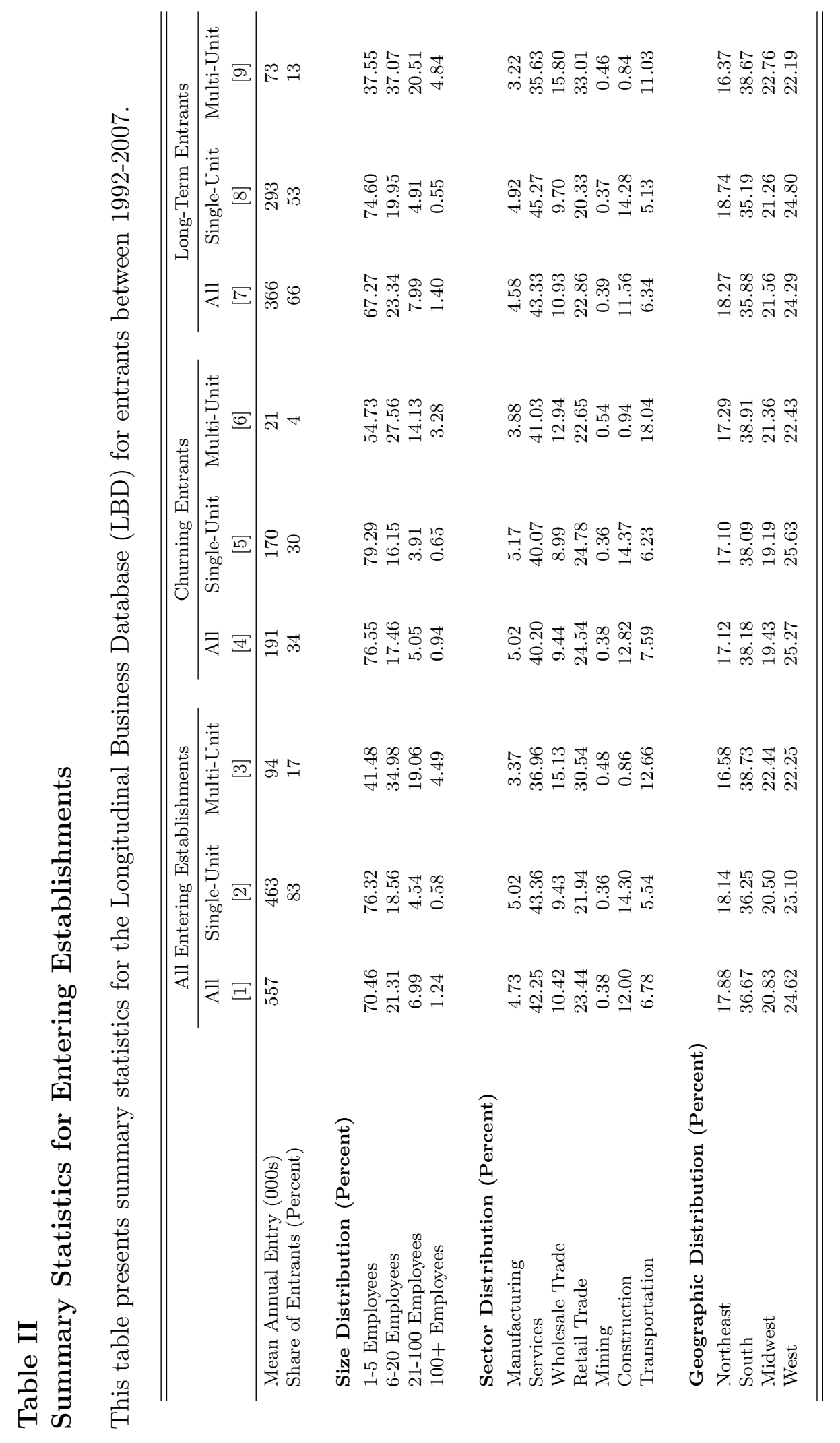




\section{Table III}

\section{Creditor Rights and Entrepreneurship: Establishment Entry and Exit}

This table presents estimates of the impact of uniform fraudulent transfer (UFTA) laws on the entry and exit of establishments. Establishment entry and exit rates at the state-year level. Analysis based on data from Longitudinal Business Database (LBD) for 1992-2007. Total entrants include establishments at their first year of positive employment. Churning entrants are defined to be entrants closing within three years of entry. Long-term entrants include entrants who did not close within three years of entry. UFTA is an indicator variable that equals one if the state has any case or statutory law defining fraud constructively, and zero otherwise. Estimations include state and year fixed effects. Standard errors (in parentheses) are clustered at the state level. ***, **, * denotes 1 percent, 5 percent, and 10 percent statistical significance.

\begin{tabular}{lcccc}
\hline \hline Dependent Variable: & $\begin{array}{c}\text { Log(Total } \\
\text { Entrants) } \\
{[1]}\end{array}$ & $\begin{array}{c}\text { Log(Churning } \\
\text { Entrants) } \\
{[2]}\end{array}$ & $\begin{array}{c}\text { Log(Long-Term } \\
\text { Entrants })\end{array}$ & $\begin{array}{c}\text { Log(Establishment } \\
\text { Closures })\end{array}$ \\
\hline UFTA & $-0.066^{* * *}$ & $-0.073^{* * *}$ & $-0.064^{* * *}$ & {$[4]$} \\
& $(0.023)$ & $(0.023)$ & $(0.025)$ & $-0.065^{* * *}$ \\
\hline State FE & $\mathrm{Y}$ & $\mathrm{Y}$ & $\mathrm{Y}$ & $\mathrm{Y}$ \\
Year FE & $\mathrm{Y}$ & $\mathrm{Y}$ & $\mathrm{Y}$ & $\mathrm{Y}$ \\
\hline Observations & 816 & 816 & 816 & 816 \\
\hline \hline
\end{tabular}




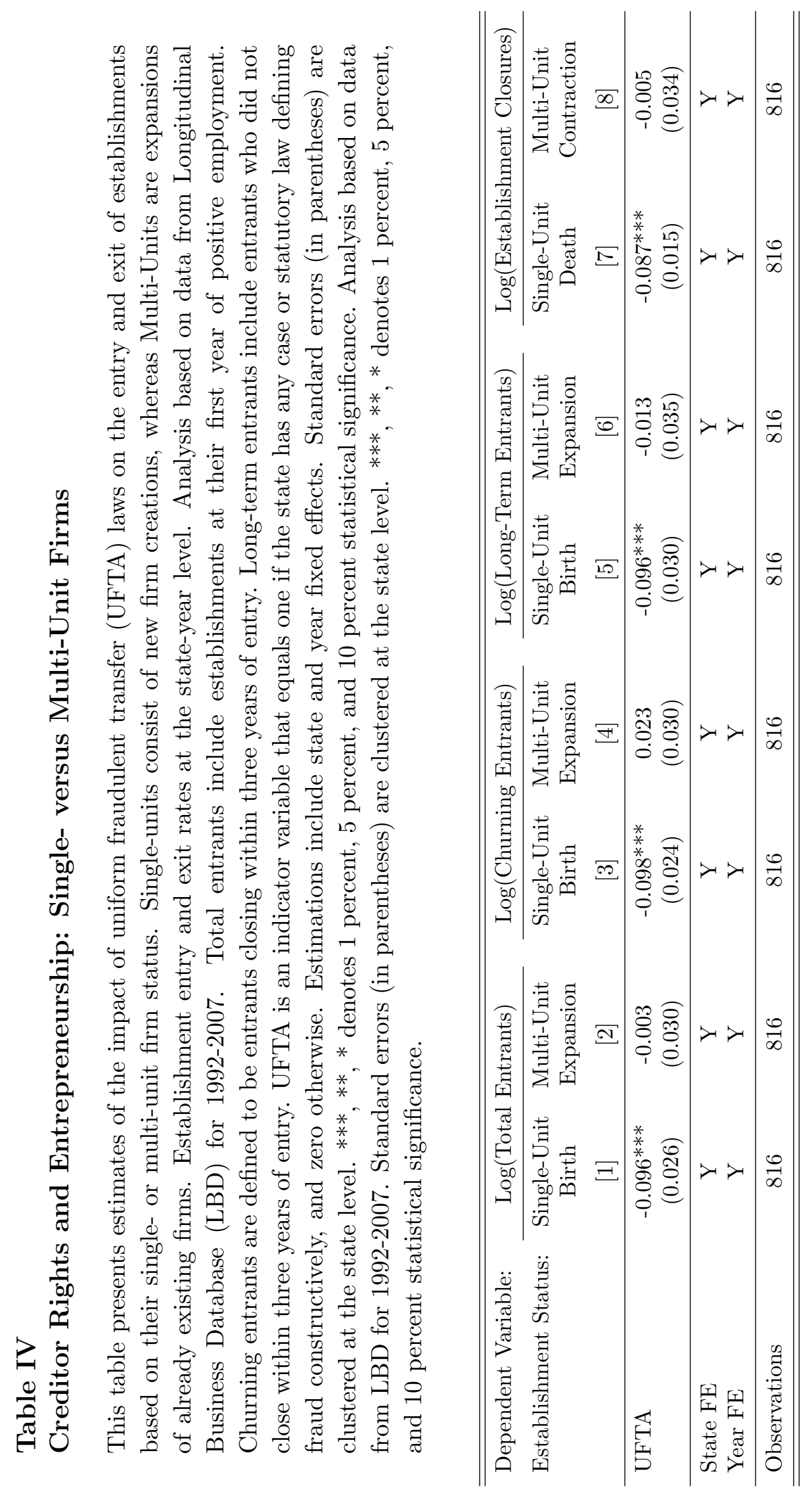




\section{Table V \\ Creditor Rights and Entrepreneurship: Dynamic Effects}

This table presents dynamic estimates of the impact of uniform fraudulent transfer (UFTA) laws on the entry and exit of single-unit firms. Single-unit firms consist of new firm creations. Establishment entry and exit rates at the state-year level. Analysis based on data from Longitudinal Business Database (LBD) for 1992-2007. The independent variables indicate the timing relative to the passage of UFTA laws in each state. Total entrants include establishments at their first year of positive employment. Churning entrants are defined to be entrants closing within three years of entry. Long-term entrants include entrants who did not close within three years of entry. UFTA is an indicator variable that equals one if the state has any case or statutory law defining fraud constructively, and zero otherwise. Estimations include state and year fixed effects. Standard errors (in parentheses) are clustered at the state level. ***,**,* denotes 1 percent, 5 percent, and 10 percent statistical significance. Analysis based on data from LBD for 1992-2007. Standard errors (in parentheses) are clustered at the state level. ***, **, * denotes 1 percent, 5 percent, and 10 percent statistical significance.

\begin{tabular}{|c|c|c|c|c|}
\hline \multirow[t]{2}{*}{ Dependent Variable: } & $\begin{array}{l}\text { Log(Total } \\
\text { Entrants) }\end{array}$ & $\begin{array}{l}\text { Log(Churning } \\
\text { Entrants })\end{array}$ & $\begin{array}{l}\text { Log(Long-Term } \\
\text { Entrants })\end{array}$ & $\begin{array}{c}\log (\text { Establishment } \\
\text { Closures })\end{array}$ \\
\hline & {$[1]$} & {$[2]$} & {$[3]$} & {$[4]$} \\
\hline UFTA $\times$ Year $(-2,-1)$ & $\begin{array}{r}-0.016 \\
(0.016)\end{array}$ & $\begin{array}{l}-0.023 \\
(0.016)\end{array}$ & $\begin{array}{l}-0.012 \\
(0.019)\end{array}$ & $\begin{array}{l}0.026 \\
(0.021)\end{array}$ \\
\hline UFTA $\times \operatorname{Year}(0,1)$ & $\begin{array}{c}0.009 \\
(0.033)\end{array}$ & $\begin{array}{c}-0.013 \\
(0.028)\end{array}$ & $\begin{array}{c}0.014 \\
(0.059)\end{array}$ & $\begin{array}{c}0.012 \\
(0.018)\end{array}$ \\
\hline UFTA $\times$ Year $(2,3)$ & $\begin{array}{c}-0.080^{* * *} \\
(0.020)\end{array}$ & $\begin{array}{c}-0.089^{* * *} \\
(0.028)\end{array}$ & $\begin{array}{c}-0.076^{* * *} \\
(0.017)\end{array}$ & $\begin{array}{l}-0.086 \\
(0.053)\end{array}$ \\
\hline UFTA $\times$ Year $(4+)$ & $\begin{array}{c}-0.092^{* * *} \\
(0.033)\end{array}$ & $\begin{array}{c}-0.113^{* * *} \\
(0.030)\end{array}$ & $\begin{array}{c}-0.083^{* * *} \\
(0.036)\end{array}$ & $\begin{array}{c}-0.058^{* *} \\
(0.028)\end{array}$ \\
\hline State FE & $\mathrm{Y}$ & $\mathrm{Y}$ & $\mathrm{Y}$ & $\mathrm{Y}$ \\
\hline Year FE & $\mathrm{Y}$ & $\mathrm{Y}$ & $\mathrm{Y}$ & $\mathrm{Y}$ \\
\hline Observations & 816 & 816 & 816 & 816 \\
\hline
\end{tabular}




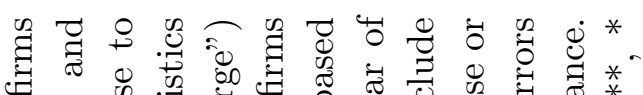

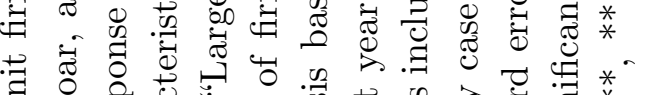

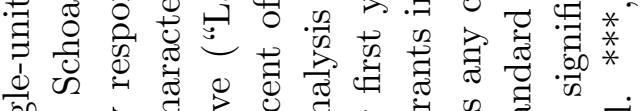

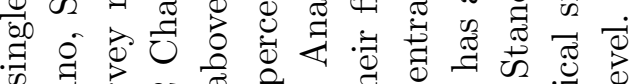

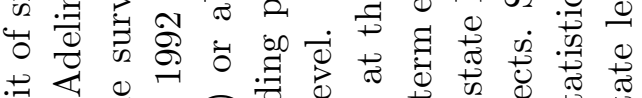

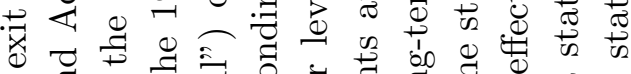

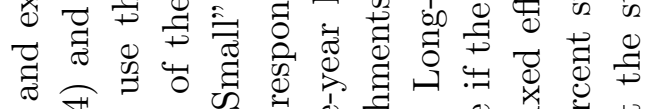

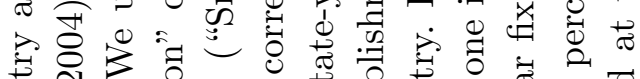

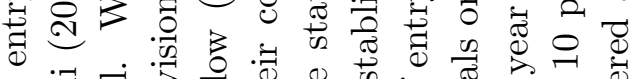

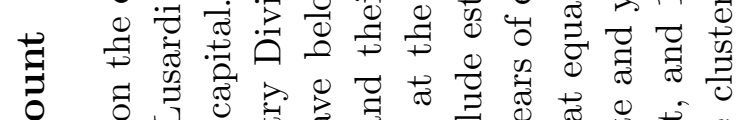

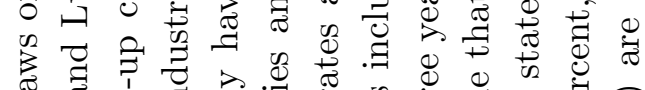

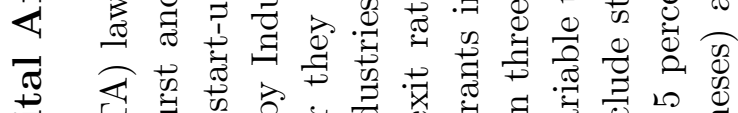

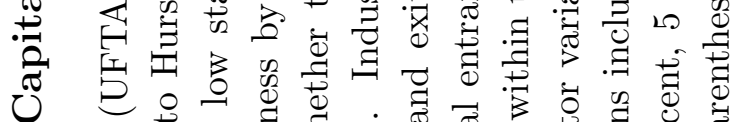

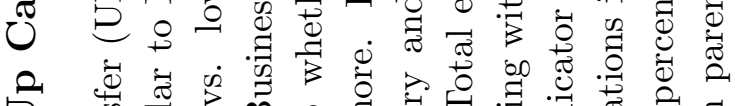

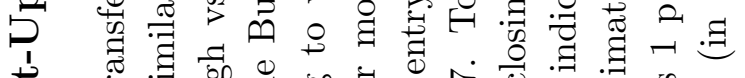

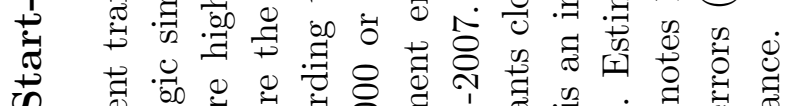

药 苞

ف 吾

品

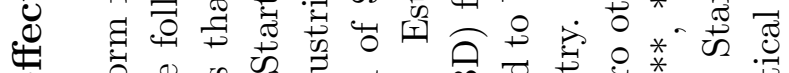

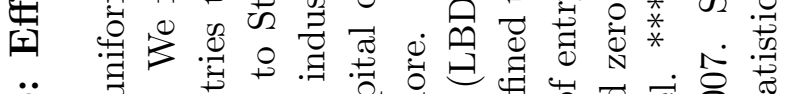

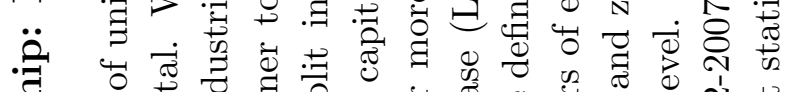

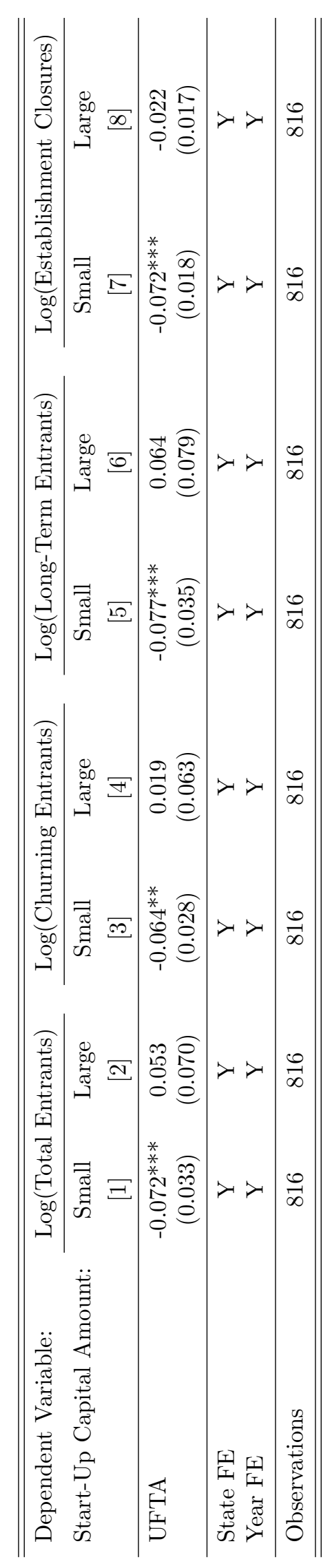

प्रै

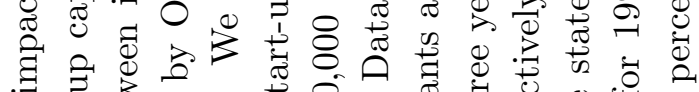

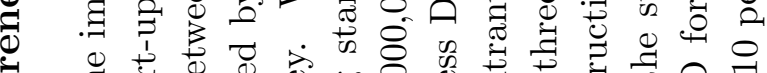

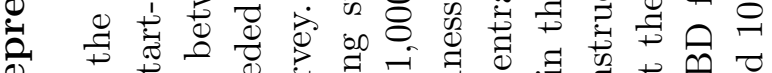

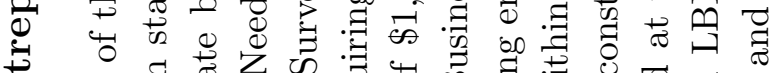

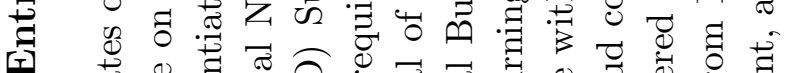

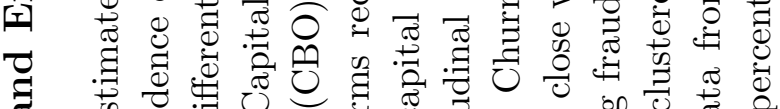

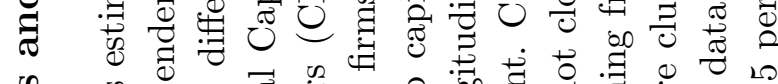

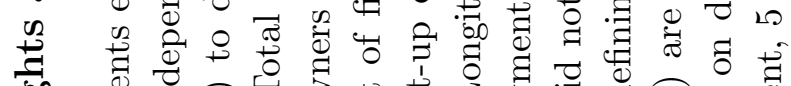

央

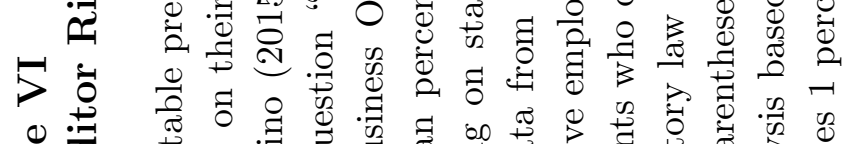

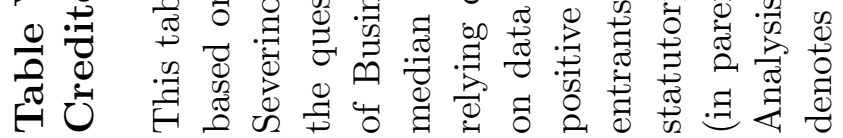




\section{Table VII \\ Creditor Rights and Entrepreneurship: Effects by Initial Employment}

This table presents estimates of the impact of uniform fraudulent transfer (UFTA) laws on the entry and exit of firms based on their initial number of employees for total, churning, and long-term entrants and final number of employees for closures. Establishment entry and exit rates at the state-year level. Analysis based on data from Longitudinal Business Database (LBD) for 1992-2007. Total entrants include establishments at their first year of positive employment. Churning entrants are defined to be entrants closing within three years of entry. Long-term entrants include entrants who did not close within three years of entry. UFTA is an indicator variable that equals one if the state has any case or statutory law defining fraud constructively, and zero otherwise. In addition to state and year fixed effects, estimations include Type fixed effects indicating whether the firm is single-unit or multi-unit. Standard errors (in parentheses) are clustered at the state level. ${ }^{* * *},{ }^{* *},{ }^{*}$ denotes 1 percent, 5 percent, and 10 percent statistical significance. Analysis based on data from LBD for 1992-2007. Standard errors (in parentheses) are clustered at the state level. ${ }^{* * *}, * *, *$ denotes 1 percent, 5 percent, and 10 percent statistical significance.

\begin{tabular}{lccccccccccc}
\hline \hline Dependent Variable: & \multicolumn{4}{c}{$\log ($ Total Entrants) } & & \multicolumn{4}{c}{$\log ($ Churning Entrants) } \\
\cline { 2 - 4 } \cline { 8 - 10 } Initial Employment: & $1-5$ & $6-20$ & $21-100$ & $101+$ & & $1-5$ & $6-20$ & $21-100$ & $101+$ \\
& {$[1]$} & {$[2]$} & {$[3]$} & {$[4]$} & & {$[5]$} & {$[6]$} & {$[7]$} & {$[8]$} \\
\hline UFTA $\times$ Single-Unit & $-0.036^{* * *}$ & 0.000 & 0.001 & $-0.015^{*}$ & & $-0.050^{* * *}$ & 0.002 & -0.006 & $-0.015^{* * *}$ \\
& $(0.012)$ & $(0.017)$ & $(0.020)$ & $(0.008)$ & & $(0.016)$ & $(0.011)$ & $(0.013)$ & $(0.005)$ \\
\hline State-Industry-Type FE & $\mathrm{Y}$ & $\mathrm{Y}$ & $\mathrm{Y}$ & $\mathrm{Y}$ & & $\mathrm{Y}$ & $\mathrm{Y}$ & $\mathrm{Y}$ & $\mathrm{Y}$ \\
State-Industry-Year FE & $\mathrm{Y}$ & $\mathrm{Y}$ & $\mathrm{Y}$ & $\mathrm{Y}$ & & $\mathrm{Y}$ & $\mathrm{Y}$ & $\mathrm{Y}$ & $\mathrm{Y}$ \\
Type-Year FE & $\mathrm{Y}$ & $\mathrm{Y}$ & $\mathrm{Y}$ & $\mathrm{Y}$ & & $\mathrm{Y}$ & $\mathrm{Y}$ & $\mathrm{Y}$ & $\mathrm{Y}$ \\
\hline Observations & 109,344 & 109,344 & 109,344 & 109,344 & & 109,344 & 109,344 & 109,344 & 109,344 \\
\hline \hline
\end{tabular}

\begin{tabular}{|c|c|c|c|c|c|c|c|c|}
\hline \multirow{3}{*}{$\begin{array}{l}\text { Dependent Variable: } \\
\text { Initial Employment: }\end{array}$} & \multicolumn{4}{|c|}{ Log(Long-Term Entrants) } & \multicolumn{4}{|c|}{ Log(Establishment Closures) } \\
\hline & $1-5$ & $6-20$ & $21-100$ & $101+$ & $1-5$ & $6-20$ & $21-100$ & $101+$ \\
\hline & {$[9]$} & {$[10]$} & {$[11]$} & {$[12]$} & {$[13]$} & {$[14]$} & {$[15]$} & {$[16]$} \\
\hline UFTA $\times$ Single-Unit & $\begin{array}{c}-0.025^{* *} \\
(0.011)\end{array}$ & $\begin{array}{l}-0.007 \\
(0.023)\end{array}$ & $\begin{array}{c}0.001 \\
(0.014)\end{array}$ & $\begin{array}{l}-0.005 \\
(0.012)\end{array}$ & $\begin{array}{c}-0.047^{* * *} \\
(0.015)\end{array}$ & $\begin{array}{l}-0.004 \\
(0.020)\end{array}$ & $\begin{array}{c}0.000 \\
(0.009)\end{array}$ & $\begin{array}{l}-0.002 \\
(0.014)\end{array}$ \\
\hline State-Industry-Type FE & $\mathrm{Y}$ & $\mathrm{Y}$ & $\mathrm{Y}$ & Y & $\mathrm{Y}$ & $\mathrm{Y}$ & Y & $\mathrm{Y}$ \\
\hline State-Industry-Year FE & Y & Y & Y & Y & Y & Y & Y & Y \\
\hline Type-Year FE & $\mathrm{Y}$ & $\mathrm{Y}$ & Y & $\mathrm{Y}$ & $\mathrm{Y}$ & $\mathrm{Y}$ & Y & $\mathrm{Y}$ \\
\hline Observations & 109,344 & 109,344 & 109,344 & 109,344 & 109,344 & 109,344 & 109,344 & 109,344 \\
\hline
\end{tabular}




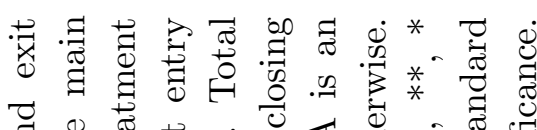

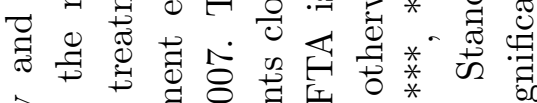
o

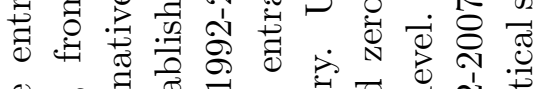

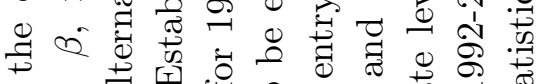
可和舟 0

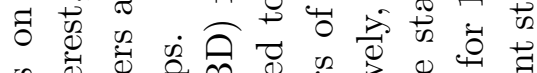

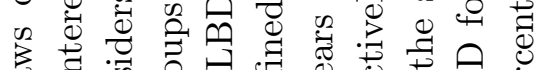

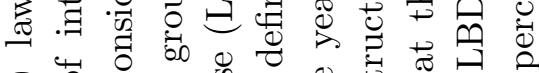

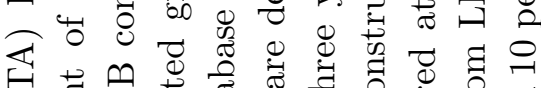

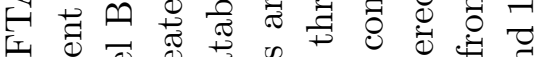

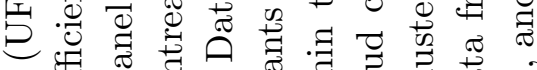

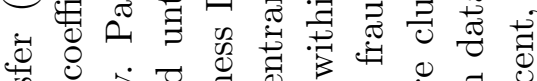
势

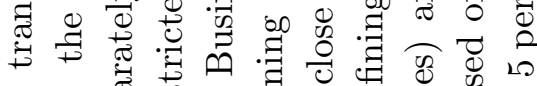

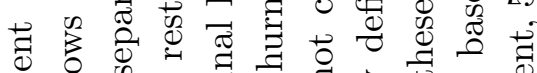

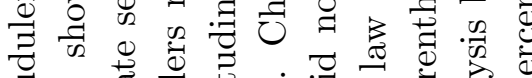

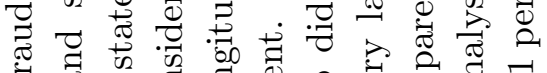

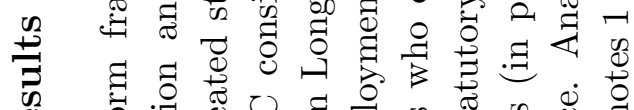

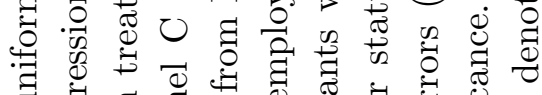
三 to

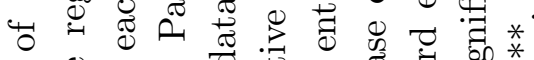

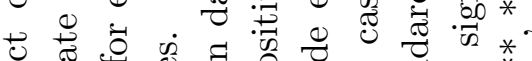

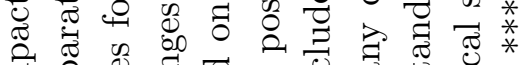

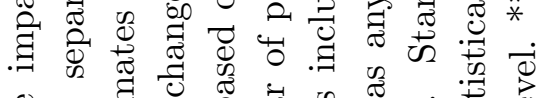
O

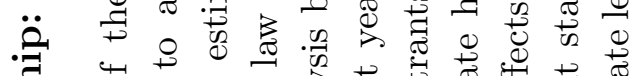
क्ष क 궁 क्ष

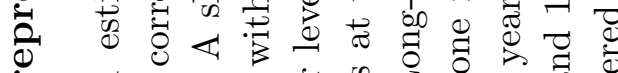

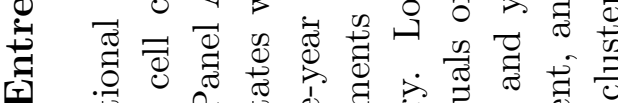
田

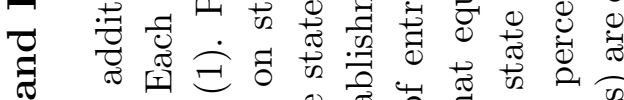

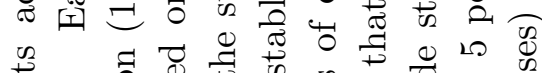

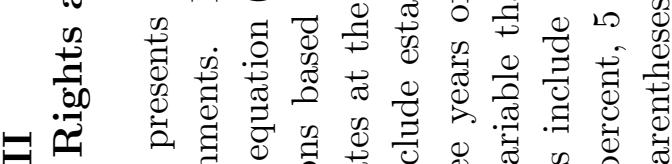

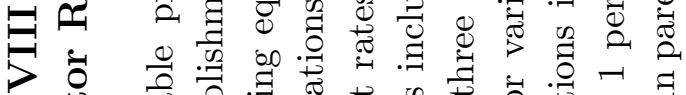
o:

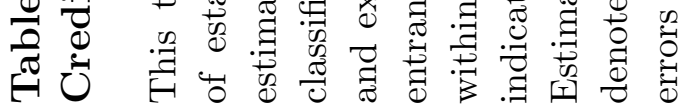

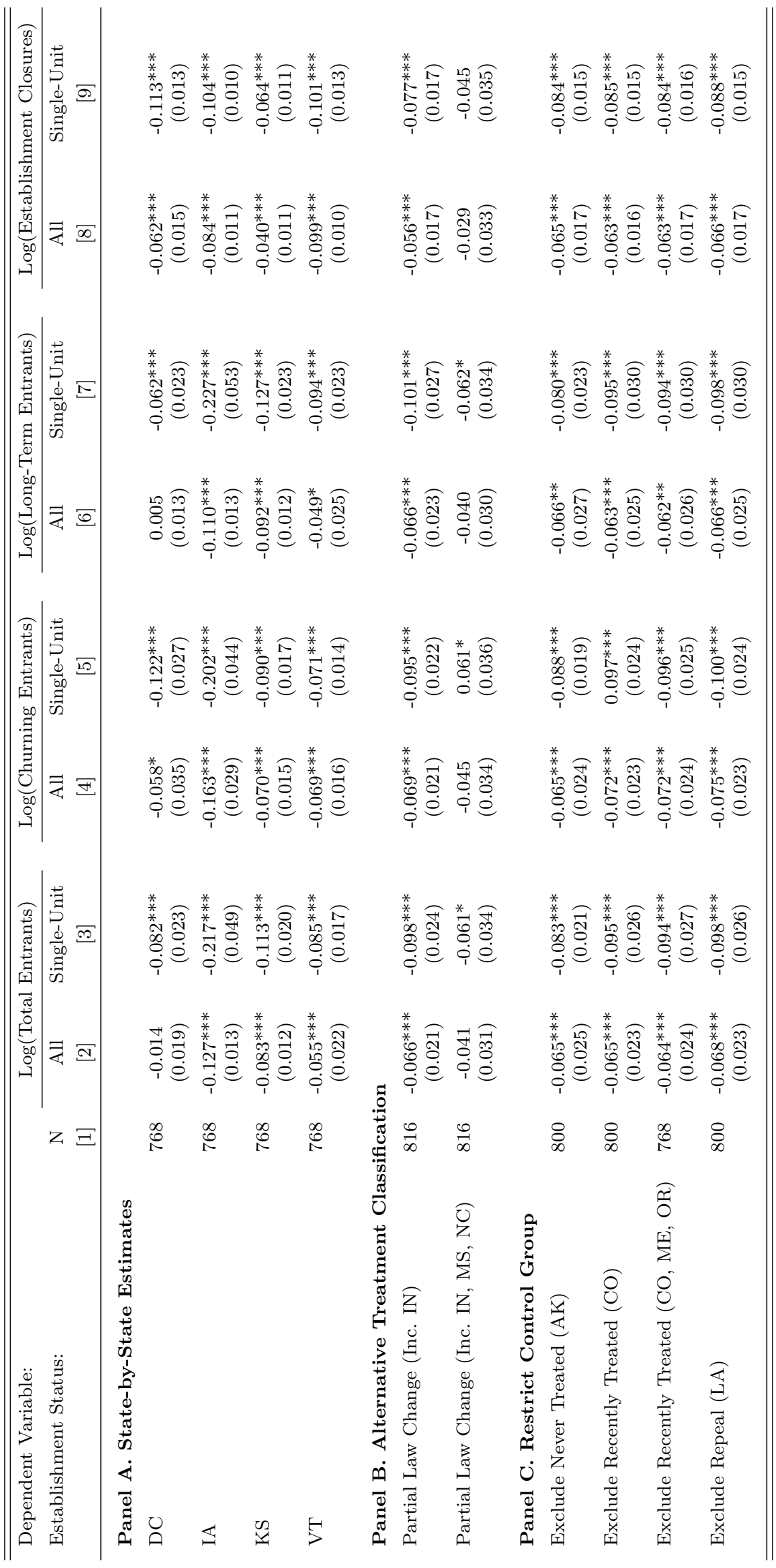




\section{Table IX}

\section{Creditor Rights and Entrepreneurship: Effect of Insider Preference Laws}

This table presents estimates of the impact of insider preference laws on entrepreneurship. Panel A presents estimates of the impact of insider laws on the entry and exit of establishments. Panel B shows establishment entry and exit rates based on their single- or multi-unit firm status. Panel C presents the dynamic estimates. Panel D analyzes the impact of insider preference laws on firms based on their initial number of employees. Establishment entry and exit rates at the state-year level. Analysis based on data from Longitudinal Business Database (LBD) for 1992-2007. Total entrants include establishments at their first year of positive employment. Churning entrants are defined to be entrants closing within three years of entry. Long-term entrants include entrants who did not close within three years of entry. UFTA is an indicator variable that equals one if the state has any case or statutory law defining fraud constructively, and zero otherwise. Estimations include state and year fixed effects. Standard errors (in parentheses) are clustered at the state level. ${ }^{* * *},{ }^{* *}, *$ denotes 1 percent, 5 percent, and 10 percent statistical significance.

\begin{tabular}{lcccc}
\hline \hline Panel A. Baseline Estimates & & & \\
Dependent Variable: & $\begin{array}{c}\text { Log(Total } \\
\text { Entrants) }\end{array}$ & $\begin{array}{c}\text { Log(Churning } \\
\text { Entrants) }\end{array}$ & $\begin{array}{c}\text { Log(Long-Term } \\
\text { Entrants) }\end{array}$ & $\begin{array}{c}\text { Log(Establishment } \\
\text { Closures) } \\
\end{array}$ \\
{$[1]$} & {$[2]$} & {$[3]$} & {$[4]$} \\
\hline Insider Preferences & -0.028 & $0.067^{*}$ & 0.008 & 0.033 \\
& $(0.032)$ & $(0.038)$ & $(0.033)$ & $(0.022)$ \\
\hline State FE & $\mathrm{Y}$ & $\mathrm{Y}$ & $\mathrm{Y}$ & $\mathrm{Y}$ \\
Year FE & $\mathrm{Y}$ & $\mathrm{Y}$ & $\mathrm{Y}$ & $\mathrm{Y}$ \\
\hline Observations & 752 & 752 & 752 & 752 \\
\hline \hline
\end{tabular}




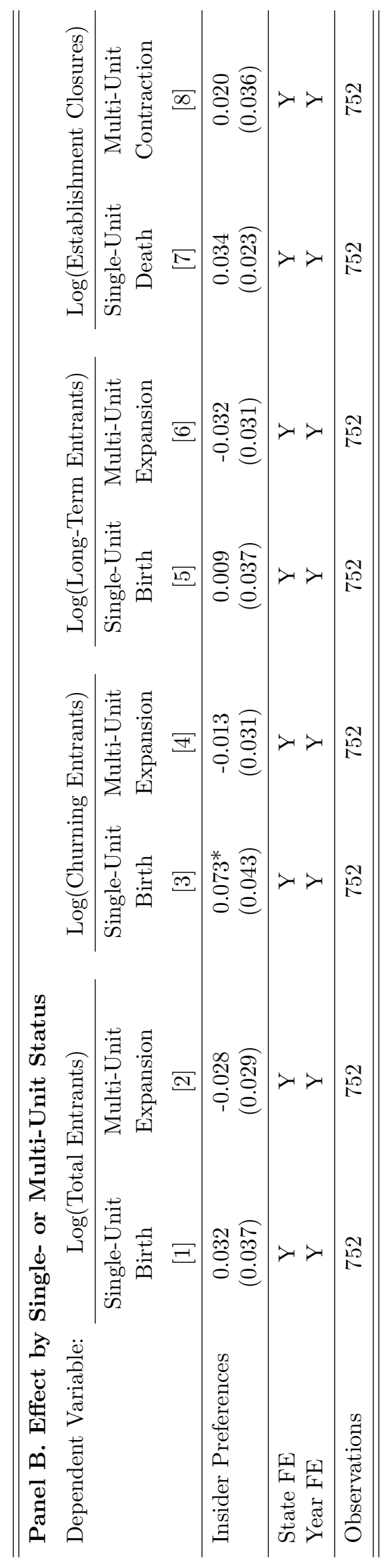




\begin{tabular}{lcccc}
\hline \hline Panel C. Dynamic Effects & & & & \\
Dependent Variable: & $\begin{array}{c}\text { Log(Total } \\
\text { Entrants) }\end{array}$ & $\begin{array}{c}\text { Log(Churning } \\
\text { Entrants) }\end{array}$ & $\begin{array}{c}\text { Log(Long-Term } \\
\text { Entrants) }\end{array}$ & $\begin{array}{c}\text { Log(Establishment } \\
\text { Closures) }\end{array}$ \\
& {$[1]$} & {$[2]$} & {$[3]$} & {$[4]$} \\
\hline Insider Preferences $\times$ Year(-2, -1) & -0.012 & -0.034 & 0.006 & -0.008 \\
& $(0.028)$ & $(0.042)$ & $(0.019)$ & $(0.025)$ \\
Insider Preferences $\times$ Year $(0,1)$ & $0.034^{* * *}$ & 0.009 & $0.054^{* * *}$ & 0.011 \\
& $(0.011)$ & $(0.012)$ & $(0.013)$ & $(0.013)$ \\
Insider Preferences $\times$ Year(2, 3) & -0.013 & 0.024 & -0.034 & 0.000 \\
& $(0.029)$ & $(0.024)$ & $(0.040)$ & $(0.031)$ \\
Insider Preferences $\times$ Year(4+) & -0.016 & 0.031 & $-0.045^{*}$ & 0.020 \\
& $(0.023)$ & $(0.031)$ & $(0.027)$ & $(0.021)$ \\
\hline State FE & $\mathrm{Y}$ & $\mathrm{Y}$ & $\mathrm{Y}$ & $\mathrm{Y}$ \\
Year FE & $\mathrm{Y}$ & $\mathrm{Y}$ & $\mathrm{Y}$ & $\mathrm{Y}$ \\
\hline Observations & 752 & 752 & 752 & 752 \\
\hline \hline
\end{tabular}

\begin{tabular}{|c|c|c|c|c|c|c|c|c|}
\hline \multicolumn{9}{|c|}{ Panel D.I. Effect by Initial Employment } \\
\hline \multirow{3}{*}{$\begin{array}{l}\text { Dependent Variable: } \\
\text { Initial Employment: }\end{array}$} & \multicolumn{4}{|c|}{ Log(Total Entrants) } & \multicolumn{4}{|c|}{ Log(Churning Entrants) } \\
\hline & $1-5$ & $6-20$ & $21-100$ & $101+$ & $1-5$ & $6-20$ & $21-100$ & $101+$ \\
\hline & {$[1]$} & {$[2]$} & {$[3]$} & {$[4]$} & {$[5]$} & {$[6]$} & {$[7]$} & {$[8]$} \\
\hline Insider Pref. $\times$ Single-Unit & $\begin{array}{l}-0.006 \\
(0.012)\end{array}$ & $\begin{array}{c}0.006 \\
(0.025)\end{array}$ & $\begin{array}{c}0.042^{* * *} \\
(0.019)\end{array}$ & $\begin{array}{c}0.019 \\
(0.020)\end{array}$ & $\begin{array}{c}0.010 \\
(0.016)\end{array}$ & $\begin{array}{c}0.020 \\
(0.022)\end{array}$ & $\begin{array}{c}0.034^{*} \\
(0.019)\end{array}$ & $\begin{array}{c}0.015 \\
(0.013)\end{array}$ \\
\hline State-Industry-Type FE & $\mathrm{Y}$ & $\mathrm{Y}$ & $\mathrm{Y}$ & $\mathrm{Y}$ & $\mathrm{Y}$ & $\mathrm{Y}$ & $\mathrm{Y}$ & $\mathrm{Y}$ \\
\hline State-Industry-Year FE & Y & $\mathrm{Y}$ & Y & $\mathrm{Y}$ & $\mathrm{Y}$ & $\mathrm{Y}$ & $\mathrm{Y}$ & Y \\
\hline Type-Year FE & Y & $\mathrm{Y}$ & $\mathrm{Y}$ & $\mathrm{Y}$ & $\mathrm{Y}$ & $\mathrm{Y}$ & $\mathrm{Y}$ & $\mathrm{Y}$ \\
\hline Observations & 100,768 & 100,768 & 100,768 & 100,768 & 100,768 & 100,768 & 100,768 & 100,768 \\
\hline \multicolumn{9}{|c|}{ Panel D.II. Effect by Initial Employment } \\
\hline Dependent Variable: & \multicolumn{4}{|c|}{ Log(Long-Term Entrants) } & \multicolumn{4}{|c|}{ Log(Establishment Closures) } \\
\hline Initial Employment: & $1-5$ & $6-20$ & $21-100$ & $101+$ & $1-5$ & $6-20$ & $21-100$ & $101+$ \\
\hline & {$[1]$} & {$[2]$} & {$[3]$} & {$[4]$} & {$[5]$} & {$[6]$} & {$[7]$} & {$[8]$} \\
\hline Insider Pref. $\times$ Single-Unit & $\begin{array}{l}-0.012 \\
(0.011) \\
\end{array}$ & $\begin{array}{c}0.003 \\
(0.023) \\
\end{array}$ & $\begin{array}{l}0.036^{*} \\
(0.02) \\
\end{array}$ & $\begin{array}{c}0.004 \\
(0.015) \\
\end{array}$ & $\begin{array}{l}-0.022 \\
(0.015) \\
\end{array}$ & $\begin{array}{l}-0.015 \\
(0.017) \\
\end{array}$ & $\begin{array}{c}0.004 \\
(0.024)\end{array}$ & $\begin{array}{l}-0.013 \\
(0.018)\end{array}$ \\
\hline State-Industry-Type FE & $\mathrm{Y}$ & $\mathrm{Y}$ & $\mathrm{Y}$ & $\mathrm{Y}$ & $\mathrm{Y}$ & $\mathrm{Y}$ & $\mathrm{Y}$ & $\mathrm{Y}$ \\
\hline State-Industry-Year FE & $\mathrm{Y}$ & $\mathrm{Y}$ & $\mathrm{Y}$ & $\mathrm{Y}$ & $\mathrm{Y}$ & $\mathrm{Y}$ & $\mathrm{Y}$ & $\mathrm{Y}$ \\
\hline Type-Year FE & $\mathrm{Y}$ & $\mathrm{Y}$ & $\mathrm{Y}$ & $\mathrm{Y}$ & $\mathrm{Y}$ & $\mathrm{Y}$ & $\mathrm{Y}$ & $\mathrm{Y}$ \\
\hline Observations & 100,768 & 100,768 & 100,768 & 100,768 & 100,768 & 100,768 & 100,768 & 100,768 \\
\hline
\end{tabular}




\section{Appendix A: Determinants of Constructive Fraud Laws}

This table presents estimates of the impact of state-level macroeconomic variables on the passage of constructive fraud laws. The sample horizon encompasses all constructive fraud changes resulting from the passage of the UFTA, from 1983-2007. UFTA is an indicator variable that equals one if the state has any case or statutory law defining fraud constructively, and zero otherwise. Total population data are from the U.S. Census. Total income data come from the Department of Commerce (Bureau of Economic Analysis). Total deposit and commercial bank and savings institution office data are from the Federal Deposit Insurance Corporation. Total new private housing unit data come from combined U.S. Census and Construction Project Reporting Survey data. Employment and labor force participation data are from the Bureau of Labor Statistics (Current Population Survey). Theft, property crime, and robbery data are from the Department of Justice (Federal Bureau of Investigation). Total school enrollment data are from the Department of Education (National Center for Education Statistics). Government loans, salary, and expenditure data are from the U.S. Census Governments Division. Estimations include state and year fixed effects. Standard errors (in parentheses) are clustered at the state level. ${ }^{* * *},{ }^{* *}$, * denotes 1 percent, 5 percent, and 10 percent statistical significance.

\begin{tabular}{lc}
\hline \hline Dependent Variable: & UFTA \\
\hline Log(Total Population) & $-1.483^{* *}$ \\
& $(0.706)$ \\
Log(Total Income) & 0.577 \\
& $(0.376)$ \\
Log(Deposits) & -0.020 \\
& $(0.031)$ \\
Log(Bank Offices) & -0.134 \\
& $(0.147)$ \\
Log(Housing) & 0.064 \\
& $(0.046)$ \\
Log(Employment) & $-2.536^{*}$ \\
& $(1.369)$ \\
Log(Labor) & $2.419^{*}$ \\
& $(1.275)$ \\
Log(Theft) & -0.207 \\
Log(Property Crime) & $(0.432)$ \\
Log(Robberies) & 0.337 \\
& $(0.436)$ \\
Log(Schools) & -0.008 \\
& $(0.127)$ \\
Log(Government Loans) & 0.137 \\
& $(0.186)$ \\
Log(Government Salaries) & 0.026 \\
Log(Government Expenditures) & $(0.030)$ \\
& 0.368 \\
State FE & $(0.232)$ \\
Year FE & $(0.178)$ \\
\hline \hline Observations & $\mathrm{Y}$ \\
\hline
\end{tabular}

